\title{
Article \\ The Safety Assessment of Toxic Metals in Commonly Used Herbs, Spices, Tea, and Coffee in Poland
}

\author{
Grażyna Kowalska
}

check for updates

Citation: Kowalska, G. The Safety Assessment of Toxic Metals in Commonly Used Herbs, Spices, Tea, and Coffee in Poland. Int. J. Environ. Res. Public Health 2021, 18, 5779. https://doi.org/10.3390/ ijerph18115779

Academic Editors: Fayuan Wang, Joanna Łuczyńska, Marek Jan Łuczyński, Magdalena Senze and Monika Kowalska-Góralska

Received: 16 April 2021

Accepted: 26 May 2021

Published: 27 May 2021

Publisher's Note: MDPI stays neutral with regard to jurisdictional claims in published maps and institutional affiliations.

Copyright: (C) 2021 by the author. Licensee MDPI, Basel, Switzerland. This article is an open access article distributed under the terms and conditions of the Creative Commons Attribution (CC BY) license (https:/ / creativecommons.org/licenses/by/ $4.0 /)$.
Department of Tourism and Recreation, University of Life Sciences in Lublin, 15 Akademicka Street, 20-950 Lublin, Poland; grazyna.kowalska@up.lublin.pl; Tel.: +48-81-445-66-53

\begin{abstract}
The presented study was aimed at the determination of the level of contamination with heavy metals $(\mathrm{Cd}, \mathrm{Pb}, \mathrm{As}$, and $\mathrm{Hg}$ ) in 240 samples of plant materials, i.e., herbal raw materials, spices, tea, and coffee. Moreover, a probabilistic risk assessment (noncarcinogenic and carcinogenic risks) was estimated by models including target hazard quotient (THQ) and cancer risk (CR). The samples were subjected to microwave mineralisation with the use of $\mathrm{HNO}_{3}(65 \%)$, while the determination of the content of the elements was performed with the use of inductively coupled plasma mass spectrometer (ICP-MS) and a mercury analyser. The element which was characterised by the highest level of accumulation in the analysed samples was lead (from 0.010 to $5.680 \mathrm{mg} / \mathrm{kg}$ ). Among the heavy metals under analysis, the lowest concentration was noted in the case of mercury (from 0.005 to $0.030 \mathrm{mg} / \mathrm{kg}$ ). A notably higher level of contamination with heavy metals was noted in the analysed samples of herbs and spices $(0.005-5.680 \mathrm{mg} / \mathrm{kg})$, compared to samples of tea and coffee $(0.005-0.791 \mathrm{mg} / \mathrm{kg})$. According to the guidelines of the World Health Organisation (WHO) concerning the limits of contamination of samples of herbal raw materials with heavy metals, lead levels exceeding the limits were only noted in 24 samples of herbs (18\%). In all of the analysed samples of spices, tea, and coffee, no instances of exceeded limits were noted for any of the analysed heavy metals. The values of TTHQmax (in relation to the consumption of the analysed products) were as follows: up to $4.23 \times 10^{-2}$ for spices, up to $2.51 \times 10^{-1}$ for herbs, up to $4.03 \times 10^{-2}$ for China tea, and up to $1.25 \times 10^{-1}$ for roasted coffee beans. As the value of THQ $\leq 1$, there is no probability of the appearance of undesirable effects related to the consumption of the analysed group of raw materials and products of plant origin. The CR value for As (max. value) was $1.29 \times 10^{-5}$, which is lower than the maximum acceptable level of $1 \times 10^{-4}$ suggested by United States Environmental Protection Agency (USEPA).
\end{abstract}

Keywords: contamination of heavy metals; herbs; spices; tea; coffee; risk assessment

\section{Introduction}

Spices and herbs grown in various regions of Poland are used as aromatic additives enhancing the sensory values of food. Although they do not contain nutrients, they are characterised by medicinal properties through antioxidant, antibacterial, anti-inflammatory, and anticarcinogenic effects. The therapeutic effect of herbal raw materials results from the medicinal properties of biologically active compounds included in their composition, such as essential oils, glycosides, vitamins, alkaloids, and tannins. Herbs and spices are also used for the purpose of alleviation of symptoms of stress, fatigue, unrest, or nervousness [1,2].

Brews of tea and coffee are the two most popular drinks. Numerous literature reports have taken note of the beneficial effect of moderate consumption of tea and coffee on human health through the regulation of the level of sugar in the blood, as well as prevention of diseases of the circulatory system and digestive system, cancers, and Parkinson's and Alzheimer's diseases [3-5].

However, in spite of the numerous beneficial characteristics of those commonly used raw materials and products of plant origin, they can also contain toxic substances accu- 
mulated from the environment. In addition, they can also be contaminated with heavy metals in the course of cultivation, as well as in the course of the processes involved in their storage and processing [6]. The accumulation of heavy metals in soil, water, and air results from incorrect waste management and from the rapid industrialisation and urbanisation of agricultural regions. Sources of inorganic contaminants of the air can be sought in the production of coal, petroleum oil, nonferrous metals, and cement. Soil contaminants are formed as a result of agricultural use of fertilisers and plant protection agents, including pesticides and fungicides containing mercury and arsenic. The water environment is contaminated with heavy metals as a result of human activity related to wastewater treatment and drying, as well as with the disposal of sewage and sanitary wastes from households $[7,8]$. Toxic elements are widely proliferated in the environment and enter the food chain, appearing in various concentrations in food and feeds. The absorption and bioaccumulation of those substances have a negative effect on the health of consumers. The most toxic elements are heavy metals, such as $\mathrm{Cd}$-cadmium, $\mathrm{Pb}-\mathrm{lead}$, As-arsenic, and Hg-mercury, which can cause a broad array of toxic and mutagenic effects. They disturb the ionic balance and mineral regulation, stimulate oxidative damage to cellular structures and DNA, and cause neoplastic transformations [9].

For this reason, the presence of heavy metals in agricultural raw materials and products should be closely monitored. Regulations concerning the maximum allowable levels of those contaminants can differ in various countries. Most of the regulations are laid down by the European Food Safety Authority, and the limits specified by the WHO for the range of the maximum concentrations of $\mathrm{Cd}, \mathrm{Pb}, \mathrm{As}$, and $\mathrm{Hg}$ in herbal raw materials are 0.3, $10.0,5.0$, and $0.2 \mathrm{mg} / \mathrm{kg}$, respectively [10]. Taking into account the health safety and life of the consumers, the present study addressed the subject matter of determination of the content of $\mathrm{Cd}, \mathrm{Pb}, \mathrm{As}$, and $\mathrm{Hg}$ in samples of herbs, spices, tea, and coffee, for the purpose of estimation of the health risk involved in the use of the abovementioned raw materials and products in Polish cuisine.

\section{Materials and Methods}

\subsection{Sample Collection}

The test material used in the study consisted of samples of unprocessed plant materials acquired at random from farms situated in the eastern part of Poland in the period of 2015-2018. Imported spices, tea, and coffee were purchased in supermarkets in Lublin. The samples were taken according to the guidelines contained in Dz.U. $2006 \mathrm{nr} 181$ poz. 1336 [11]. The minimal weight of a sample was $3 \mathrm{~kg}$. A total of 240 samples were analysed. The samples were classified into four groups:

1. Herbs (163)

- Green matter: hoary rockrose (Cistus incanus L.)-(7), lemon balm (Melissa officinalis L.) - (4), common sage (Salvia officinalis L.) -(4), common thyme (Thymus vulgaris L.) (3), field horsetail (Equisetum arvense L.) -(3), heath speedwell (Veronica officinalis L.)-(3), common mugwort (Artemisia vulgaris L.)-(3), yellow bedstraw (Galium verum L.) (3), ground ivy (Glechoma hederacea L.)-(3), smallflower hairy willowherb (Epilobium parviflorum Schreb.)-(3), southernwood (Artemisia abrotanum L.) - (3), common oat (Avena sativa L.)-(3);

- $\quad$ Root: valerian (Valeriana officinalis L.) -(17), liquorice (Glycyrrhiza glabra L.)-(8), dandelion (Taraxacum officinale Web.) - (4), greater burdock (Arctium lappa L.) (3), Japanese knotweed (Reynoutria japonica Houtt.) - (3), marshmallow (Althaea officinalis L.) -(3), common chicory (Cichorium intybus L.)-(3),

- Leaf: European blueberry (Vaccinium myrtillus L.)-(3), blackcurrant (Ribes nigrum L.) - (3), white mulberry (Morus alba L.) - (3), globe artichoke (Cynara scolymus L.) - (3), red raspberry (Rubus idaeus L.) - (3), goutweed (Aegopodium podagraria L.)-(3), bear's garlic (Allium ursinum L.)-(3);

- $\quad$ Flower: blackthorn (Prunus spinosa L.) - (3), red clover (Trifolium pratense L.)(3), common heather (Calluna vulgaris L.)—(3), hollyhock (Alcea rosea L.)—(3), 
chamomile (Matricaria chamomilla L.)—(4), common sunflower (Helianthus annuus L.) -(3), small-leaved lime (Tilia cordata Mill.)—(3), white nettle (Lamium album L.)-(3);

- $\quad$ Fruit: dog rose (Rosa canina L.)-(3), rowan (Sorbus aucuparia L.) -(4), midland hawthorn (Crataegus oxyacantha L.) -(3), chasteberry (Vitex agnus-castus L.) -(3);

- Seeds: common flax (Linum usitatissimum L.) - (24), narrowleaf plantain (Plantago lanceolata L.)-(3).

2. Spices (61)

- Green matter of basil (Ocimum basilicum L.)-(3);

- $\quad$ Rhizome: common onion (Allium cepa L.)-(3), common garlic (Allium sativum L.)-(3);

- $\quad$ Root of turmeric (Curcuma longa L.)-(3);

- $\quad$ Flowers of clove tree (Eugenia caryophyllus L.)-(3);

- $\quad$ Fruit: black pepper (Piper nigrum L.)—(26), peppers (Capsicum annuum L.)-(8), allspice (Pimenta dioica L.)-(3);

- $\quad$ Seeds: cumin (Cuminum cyminum L.) -(3), fennel (Foeniculum vulgare Mill.)—(3), fenugreek (Trigonella foenum-graecum L.)-(3).

3. Leaf of China tea (green) (8).

4. Beans of Arabica coffee (roasted) (8).

Prior to the analyses, the samples tested were homogenised and ground as required (plant samples were milled and sieved through a $0.5 \mathrm{~mm}$ mesh), after which the moisture level of each product was measured for conversion to dry matter. The plant material was standardised through pooling together and fragmentation to a homogeneous fraction with the use of a laboratory analytical mill type A11 Basic (IKA), after which, using a moisture analyser type WPS 50 SX (RAD WAG, Poland), the moisture content of every product was determined in the aspect of conversion to dry matter.

\subsection{Evaluation of the Contents of $\mathrm{Cd}, \mathrm{Pb}, \mathrm{As}$, and $\mathrm{Hg}$}

The content of metals in the analysed samples was determined following microwave mineralisation [12]. Approximately $0.5 \mathrm{~g}$ of each plant sample was placed in a Teflon vessel. Then, $10 \mathrm{~mL}$ of $65 \% \mathrm{HNO}_{3}$ (suprapur grade) supplied by (Merck, Darmstadt, Germany) was added to the vessel, and the sealed vessel was put into a microwave mineraliser MARS Express (CEM, Matthews, NC, USA). The microwave mineralisation was performed stepwise at $400 \mathrm{~W}$ and $363 \mathrm{~K}$, at $800 \mathrm{~W}$ and $393 \mathrm{~K}$, and at $1600 \mathrm{~W}$ and $483 \mathrm{~K}$. The cooled digestion solution was then diluted to $50 \mathrm{~mL}$ using high-purity deionised water.

\subsection{ICP-MS}

To determine $\mathrm{Pb}, \mathrm{Cd}$, and As content in the plant samples, an inductively coupled plasma mass spectrometer ICP-MS 820-MS (Varian, Mulgrave, Australia) with quadrupole mass analyser was used. The instrumental conditions for trace-element determination by ICP-MS were as follows: plasma: argon plasma; plasma flow: $18 \mathrm{~L} / \mathrm{min}$; auxiliary flow: $1.8 \mathrm{~L} / \mathrm{min}$; stealth gas flow: $0.12 \mathrm{~L} / \mathrm{min}$; nebuliser flow: $0.95 \mathrm{~L} / \mathrm{min}$; sampling depth: $6 \mathrm{~mm}$; RF power: $1.35 \mathrm{~kW}$; pump rate: $0.1 \mathrm{~Hz}$; stabilisation delay: $35 \mathrm{~s}$; first extraction lens: $5 \mathrm{~V}$; second extraction lens: $190 \mathrm{~V}$; third extraction lens: $225 \mathrm{~V}$; corner lens: $200 \mathrm{~V}$; left mirror lens: $39 \mathrm{~V}$; right mirror lens: $34 \mathrm{~V}$; bottom mirror lens: $36 \mathrm{~V}$; entrance lens: $1.00 \mathrm{~V}$; fringe bias: $-2.90 \mathrm{~V}$; entrance plate: $-39 \mathrm{~V}$.

All certified single-element standard solutions used to prepare the calibration curve (1000 mg/L) used were of the highest purity grade (99.999\%) and were supplied by Ultra Scientific. The blank calibration standards for ICP-MS analysis were prepared by diluting solutions in $1 \% \mathrm{HNO}_{3}$ and in high-purity deionised water. Each sample, depending on the plant material, was diluted appropriately to the range of the standard curve. The results were expressed in $\mathrm{mg} / \mathrm{kg}$ of dry matter (DM). 


\subsection{Mercury Analyzer}

Mercury was determined independently using a non-flame atomic spectrometry absorption technique (mercury analyser AMA 254, Altec, Czech Republic) according to a previously described method [13]. The original factory calibration was still valid for the calibration of the instrument. The values were controlled regularly by calibration standard mercury solutions-NIST-traceable Hg standard solution (Accu Trace Single Element Standard; AccuStandard Inc., New Haven, CT, USA) [13].

\subsection{Analytical Quality}

During the analysis of $\mathrm{Hg}, \mathrm{Cd}, \mathrm{Pb}$, and As, the analytical quality was controlled by means of measurement of a blind sample, a double sample, and the certified reference materials: tea leaves (INCT-TL-1) and mixed polish herbs (INCT-MPH-2) (Table 1).

Table 1. Validation parameters of the analytical procedure for the determination of $\mathrm{Cd}, \mathrm{Pb}, \mathrm{As}$, and $\mathrm{Hg}$.

\begin{tabular}{ccccc}
\hline \multirow{2}{*}{ Validation Parameters } & \multicolumn{5}{c}{ Metals } \\
\cline { 2 - 5 } & $\mathbf{H g}$ & $\mathbf{C d}$ & $\mathbf{P b}$ & $\mathbf{A s}$ \\
\hline LOD * $(\mathrm{mg} / \mathrm{kg})$ & 0.002 & 0.01 & 0.005 & 0.05 \\
LOQ $^{* *}(\mathrm{mg} / \mathrm{kg})$ & 0.005 & 0.02 & 0.01 & 0.1 \\
Linearity & 0.9999 & 0.9999 & 0.9999 & 0.9999 \\
Working range $(\mathrm{mg} / \mathrm{kg})$ & $0.005-5$ & $0.02-2$ & $0.01-5$ & $0.1-10$ \\
Reproducibility (\%) & 3.80 & 2.42 & 6.07 & 3.18 \\
Recovery (\%) & 90 & 99 & 99 & 101 \\
Expanded uncertainty (\%) & 24 & 6 & 12 & 7 \\
\hline
\end{tabular}

$\mathrm{Hg}$ (mercury), $\mathrm{Cd}$ (cadmium), $\mathrm{Pb}$ (lead), As (arsenic) Validation parameters were determined on the basis of 20 repetitions. ${ }^{*}$ LOD-limit of detection. ${ }^{* *}$ LOQ- limit of quantitation.

\subsection{Health Risk Assessment}

The health risk assessment (noncarcinogenic hazard) related to the presence of heavy metals in analysed samples was performed using a previously described model [14]. The target hazard quotient (THQ) was used for the calculation of noncarcinogenic hazard of ingestion of heavy metals (Equation (1)) [14,15].

$$
\mathrm{THQ}=(\mathrm{EFi} \times \mathrm{EDi} \times \mathrm{MSi} \times \mathrm{C}) /(\mathrm{RfD} \times \mathrm{BWi} \times \mathrm{AT}) .
$$

The estimated daily intake EDI (mg analysed element $\mathrm{kg} /$ body weight/day) was calculated using the following equation $[14,16]$ :

$$
\mathrm{EDI}=(\mathrm{MSi} \times \mathrm{C}) / \mathrm{BWi},
$$

where $C$ is the trace element concentration in canned meat and canned fish (expressed as $\mu \mathrm{g} / \mathrm{kg}$ w.w. in EDI and as $\mu \mathrm{g} / \mathrm{kg}$ in THQ), MSi is the mass of selected dietary ingested in adults (average daily consumption of investigated products in Poland: spices$0.7 \mathrm{~g} /$ day [17], tea-2.7 g/day [18], coffeee $-7.8 \mathrm{~g} /$ day [19], herbs— $0.7 \mathrm{~g} /$ day [20]), EFi is the exposure frequency (365 days/year), Edi is the exposure duration (70 years), BWi is the average body weight $(70 \mathrm{~kg})$, and AT is the average exposure time for noncarcinogens (365 days/year $\times$ ED).

When THQ $>1$, there is a probability of potentially harmful effects occurring, while, when THQ $\leq 1$, there is no probability of unfavourable effects [15].

$\mathrm{RfD}$ is the heavy metal oral intake reference dose (mg/ $\mathrm{kg} /$ day). The RfDs for lead, mercury, cadmium, and arsenic are $0.0036,0.0003,0.001$, and $0.0003 \mathrm{mg} / \mathrm{kg} / \mathrm{day}$, respectively [21-23]. 
In order to estimate total target hazard quotient (TTHQ) for multiple heavy metals, the sum of THQi for individual heavy metals was estimated using Equation $(3)[15,21]$.

$$
\mathrm{TTHQ}=\sum_{\mathrm{i}=1}^{\mathrm{n}} \mathrm{THQi} .
$$

As an estimate, carcinogenic risk (CR) was calculated using Equation (4) $[15,22]$.

$$
\mathrm{CR}=\mathrm{EDI} \times \mathrm{SF}
$$

where $\mathrm{CF}$ is the cancer slope factor $(\mathrm{mg} / \mathrm{kg} /$ day), i.e., the probability of the substance to increase cancer risk via the oral exposure route. CR is estimated as the incremental probability of an individual developing cancer over a lifetime. For example, a CR of $10^{-4}$ indicates a probability of 1 in 10,000 individuals developing cancer. Risks in the range of $1.0 \times 10^{-6}$ to $1.0 \times 10^{-4}$ are acceptable $[15,22]$.

Arsenic was treated as a potential carcinogenic contaminant, whereas lead and mercury were regarded as noncarcinogenic elements, according to the order of the classification group defined by the International Agency for Research on Cancer [24]. The CF for arsenic is $1.5 \mathrm{mg} / \mathrm{kg} /$ day [25]. The CFs for $\mathrm{Cd}, \mathrm{Hg}$, and $\mathrm{Pb}$ were not available. In this study, the value of estimated $\mathrm{CR}$ was compared with the maximum acceptable risk suggested by the USEPA, which is $\leq 1.0 \times 10^{-4}$ [22].

\section{Results and Discussion}

The results of the analysis of heavy metals in selected samples of herbs, spices, tea, and coffee are presented in Table 2. To determine the degree of contamination of the analysed samples with heavy metals, the presented results were referenced to the guidelines of the World Health Organisation (WHO) and the Commission Regulation (EU) No. 420/2011, setting maximum allowable levels of certain contaminants in fresh herbs, in conversion to dry matter, with the assumption of water content at the level of $90 \%$.

\subsection{Cadmium}

In the analysed samples of herbs, the content of cadmium was diversified in relation to the species and varied within the range from $<\mathrm{LOQ}(0.020 \mathrm{mg} / \mathrm{kg})$ to $2.170 \mathrm{mg} / \mathrm{kg}$. Among the 163 analysed samples of herbs, in 24 samples (15\%), the assayed cadmium levels exceeded the limit values set by the World Health Organisation (WHO) at the level of $0.3 \mathrm{mg} / \mathrm{kg}$ [10]. Excessive values were noted for nine herbal species-green matter of hoary rockrose, heath speedwell, yellow bedstraw, southernwood, root of marshmallow, leaves of globe artichoke and red raspberry, flower of hollyhock, and fruit of midland hawthorn. In accordance with the guidelines of the Commission Regulation (EU) No. 420/2011 setting maximum allowable levels of certain contaminants in fresh herbs, in conversion to dry matter, in one sample of the cistus herb, it was found that the allowable cadmium content was exceeded-2.17 mg/ $\mathrm{kg}$. In 41 samples $(25 \%)$ of 12 species of herbs (green matter of field horsetail, root of liquorice and dandelion, leaves of white mulberry and goutweed, flower of red clover, common heather, common sunflower and white nettle, fruit of dog rose and chasteberry, and seeds of narrowleaf plantain), no presence of cadmium was found in any of the analysed samples. The lowest levels of cadmium, within the range from 0.020 to $0.333 \mathrm{mg} / \mathrm{kg}$, were noted in samples of green matter of lemon balm, common sage, common thyme, ground ivy, common oat, and smallflower hairy willowherb, root of valerian, greater burdock, Japanese knotweed, and common chicory, leaves of European blueberry, and bear's garlic, flowers of blackthorn, camomile, and small-leaved lime, fruit of rowan, and seeds of common flax. The highest concentrations of cadmium were assayed in samples of green matter of hoary rockrose and common mugwort and leaves of globe artichoke, at $2.170 \mathrm{mg} / \mathrm{kg}, 1.670 \mathrm{mg} / \mathrm{kg}$, and $0.654 \mathrm{mg} / \mathrm{kg}$, respectively. 
Table 2. The heavy-metal contents in selected samples of herbs, spices, tea, and coffee.

\begin{tabular}{|c|c|c|c|c|c|c|}
\hline Parts Used & Botanical Name & $\begin{array}{c}\text { Samples } \\
\text { Analysed }\end{array}$ & $\mathrm{Cd}(\mathrm{mg} / \mathrm{kg})$ & $\mathrm{Pb}(\mathrm{mg} / \mathrm{kg})$ & As (mg/kg) & $\mathrm{Hg}$ (mg/kg) \\
\hline \multicolumn{7}{|c|}{ Herbs } \\
\hline \multirow{12}{*}{ Herbs } & $\begin{array}{l}\text { Hoary rockrose } \\
\text { Cistus incanus L. }\end{array}$ & 7 & $\begin{array}{c}<\mathrm{LOQ}=0.02-2.17 \\
0.935\end{array}$ & $\begin{array}{c}<\mathrm{LOQ}=0.01-2.01 \\
0.979\end{array}$ & $<\mathrm{LOQ}=0.1$ & $\begin{array}{c}<\mathrm{LOQ}=0.005-0.016 \\
0.009\end{array}$ \\
\hline & $\begin{array}{c}\text { Lemon balm } \\
\text { Melissa officinalis L. }\end{array}$ & 4 & $\begin{array}{l}0.026-0.040 \\
0.034\end{array}$ & $\begin{array}{c}0.531-3.47 \\
1.91\end{array}$ & $<\mathrm{LOQ}=0.1$ & $<\mathrm{LOQ}=0.005$ \\
\hline & $\begin{array}{l}\text { Common sage } \\
\text { Salvia officinalis L. }\end{array}$ & 4 & $\begin{array}{c}<\mathrm{LOQ}=0.02-0.035 \\
0.009\end{array}$ & $\begin{array}{l}1.96-2.55 \\
2.21\end{array}$ & $<\mathrm{LOQ}=0.1$ & $<\mathrm{LOQ}=0.005$ \\
\hline & $\begin{array}{l}\text { Common thyme } \\
\text { Thymus vulgaris L. }\end{array}$ & 3 & $\begin{array}{c}0.102-0.147 \\
0.125\end{array}$ & $<\mathrm{LOQ}=0.01$ & $<\mathrm{LOQ}=0.1$ & $<\mathrm{LOQ}=0.005$ \\
\hline & $\begin{array}{c}\text { Field horsetail } \\
\text { Equisetum arvense L. }\end{array}$ & 3 & $<\mathrm{LOQ}=0.02$ & $<\mathrm{LOQ}=0.01$ & $<\mathrm{LOQ}=0.1$ & $\begin{array}{c}0.007-0.020 \\
0.015\end{array}$ \\
\hline & $\begin{array}{l}\text { Heath speedwell } \\
\text { Veronica officinalis L. }\end{array}$ & 3 & $\begin{array}{c}0.399-0.485 \\
0.453\end{array}$ & $\begin{array}{l}0.99-1.15 \\
1.07\end{array}$ & $<\mathrm{LOQ}=0.1$ & $<\mathrm{LOQ}=0.005$ \\
\hline & $\begin{array}{l}\text { Common mugwort } \\
\text { Artemisia vulgaris L. }\end{array}$ & 3 & $\begin{array}{c}1.39-1.67 \\
1.53\end{array}$ & $\begin{array}{c}0.482-0.601 \\
0.554\end{array}$ & $<\mathrm{LOQ}=0.1$ & $\begin{array}{c}0.006-0.008 \\
0.007\end{array}$ \\
\hline & $\begin{array}{l}\text { Yellow bedstraw } \\
\text { Galium verum L. }\end{array}$ & 3 & $\begin{array}{l}0.380-0.481 \\
0.434\end{array}$ & $\begin{array}{c}0.189-0.246 \\
0.209\end{array}$ & $<\mathrm{LOQ}=0.1$ & $<\mathrm{LOQ}=0.005$ \\
\hline & $\begin{array}{c}\text { Ground ivy } \\
\text { Glechoma hederacea L. }\end{array}$ & 3 & $\begin{array}{l}0.157-0.201 \\
0.183\end{array}$ & $\begin{array}{c}0.295-0.405 \\
0.359\end{array}$ & $<\mathrm{LOQ}=0.1$ & $\begin{array}{c}0.009-0.017 \\
0.012\end{array}$ \\
\hline & $\begin{array}{l}\text { Smallflower hairy } \\
\text { willowherb } \\
\text { Epilobium parviflorum } \\
\text { Schreb. }\end{array}$ & 3 & $\begin{array}{c}<\mathrm{LOQ}=0.02-0.119 \\
0.040\end{array}$ & $\begin{array}{c}0.328-0.588 \\
0.460\end{array}$ & $<\mathrm{LOQ}=0.1$ & $\begin{array}{c}0.006-0.007 \\
0.006\end{array}$ \\
\hline & $\begin{array}{c}\text { Southernwood } \\
\text { Artemisia abrotanum L. }\end{array}$ & 3 & $\begin{array}{c}0.295-0.427 \\
0.368\end{array}$ & $\begin{array}{l}1.20-1.85 \\
1.57\end{array}$ & $<\mathrm{LOQ}=0.1$ & $<\mathrm{LOQ}=0.005$ \\
\hline & $\begin{array}{l}\text { Common oat } \\
\text { Avena sativa L. }\end{array}$ & 3 & $\begin{array}{c}<\mathrm{LOQ}=0.02-0.053 \\
0.018\end{array}$ & $\begin{array}{c}0.022-0.343 \\
0.197\end{array}$ & $<\mathrm{LOQ}=0.1$ & $<\mathrm{LOQ}=0.005$ \\
\hline \multirow{7}{*}{ Rhizome } & $\begin{array}{c}\text { Valerian } \\
\text { Valeriana officinalis L. }\end{array}$ & 17 & $\begin{array}{c}<\mathrm{LOQ}=0.02-0.333 \\
0.117\end{array}$ & $\begin{array}{c}0.120-5.68 \\
1.730\end{array}$ & $\begin{array}{c}<\mathrm{LOQ}=0.1-0.535 \\
0.127\end{array}$ & $\begin{array}{c}<\mathrm{LOQ}=0.005-0.013 \\
0.003\end{array}$ \\
\hline & $\begin{array}{c}\text { Liquorice } \\
\text { Glycyrrhiza glabra L. }\end{array}$ & 8 & $<\mathrm{LOQ}=0.02$ & $\begin{array}{c}0.174-0.334 \\
0.270\end{array}$ & $<\mathrm{LOQ}=0.1$ & $<\mathrm{LOQ}=0.005$ \\
\hline & $\begin{array}{c}\text { Dandelion } \\
\text { Taraxacum officinale Web. }\end{array}$ & 3 & $<\mathrm{LOQ}=0.02$ & $\begin{array}{c}0.299-0.407 \\
0.337\end{array}$ & $<\mathrm{LOQ}=0.1$ & $<\mathrm{LOQ}=0.005$ \\
\hline & $\begin{array}{l}\text { Greater burdock } \\
\text { Arctium lappa L. }\end{array}$ & 3 & $\begin{array}{c}<\mathrm{LOQ}=0.02-0.316 \\
0.189\end{array}$ & $\begin{array}{c}0.36-0.46 \\
0.41\end{array}$ & $<\mathrm{LOQ}=0.1$ & $<\mathrm{LOQ}=0.005$ \\
\hline & $\begin{array}{c}\text { Japanese knotweed } \\
\text { Reynoutria japonica } \\
\text { Houtt. }\end{array}$ & 3 & $\begin{array}{c}0.052-0.128 \\
0.077\end{array}$ & $\begin{array}{l}0.28-0.35 \\
0.30\end{array}$ & $<\mathrm{LOQ}=0.1$ & $<\mathrm{LOQ}=0.005$ \\
\hline & $\begin{array}{c}\text { Marshmallow } \\
\text { Althaea officinalis L. }\end{array}$ & 3 & $\begin{array}{c}0.220-0.461 \\
0.340\end{array}$ & $\begin{array}{c}0.258-0.389 \\
0.331\end{array}$ & $<\mathrm{LOQ}=0.1$ & $\begin{array}{c}0.006-0.007 \\
0.006\end{array}$ \\
\hline & $\begin{array}{l}\text { Common chicory } \\
\text { Cichorium intybus L. }\end{array}$ & 3 & $\begin{array}{c}0.075-0.124 \\
0.091\end{array}$ & $\begin{array}{l}0.073-0.201 \\
0.116\end{array}$ & $<\mathrm{LOQ}=0.1$ & $\begin{array}{c}0.006-0.007 \\
0.006\end{array}$ \\
\hline \multirow{6}{*}{ Leaves } & $\begin{array}{l}\text { European blueberry } \\
\text { Vaccinium myrtillus L. }\end{array}$ & 3 & $\begin{array}{c}0.202-0.322 \\
0.256\end{array}$ & $\begin{array}{c}1.23-1.99 \\
0.60\end{array}$ & $<\mathrm{LOQ}=0.1$ & $\begin{array}{l}0.010-0.030 \\
0.02\end{array}$ \\
\hline & $\begin{array}{l}\text { Blackcurrant } \\
\text { Ribes nigrum L. }\end{array}$ & 3 & $\begin{array}{c}0.223-0.382 \\
0.287\end{array}$ & $\begin{array}{l}0.198-0.281 \\
0.230\end{array}$ & $\begin{array}{c}0.166-0.202 \\
0.184\end{array}$ & $<\mathrm{LOQ}=0.005$ \\
\hline & $\begin{array}{l}\text { White mulberry } \\
\text { Morus alba L. }\end{array}$ & 3 & $<\mathrm{LOQ}=0.02$ & $\begin{array}{c}<\mathrm{LOQ}=0.01-0.20 \\
0.067\end{array}$ & $<\mathrm{LOQ}=0.1$ & $\begin{array}{c}<\mathrm{LOQ}=0.005-0.015 \\
0.009\end{array}$ \\
\hline & $\begin{array}{l}\text { Globe artichoke } \\
\text { Cynara scolymus L. }\end{array}$ & 3 & $\begin{array}{c}0.554-0.654 \\
0.603\end{array}$ & $<\mathrm{LOQ}=0.01$ & $<\mathrm{LOQ}=0.1$ & $<\mathrm{LOQ}=0.005$ \\
\hline & $\begin{array}{l}\text { Red raspberry } \\
\text { Rubus idaeus L. }\end{array}$ & 3 & $\begin{array}{l}0.211-0.613 \\
0.345\end{array}$ & $\begin{array}{c}0.242-0.507 \\
0.330\end{array}$ & $<\mathrm{LOQ}=0.1$ & $\begin{array}{c}<\mathrm{LOQ}=0.005-0.010 \\
0.007\end{array}$ \\
\hline & $\begin{array}{c}\text { Goutweed } \\
\text { Aegopodium podagraria L. }\end{array}$ & 3 & $<\mathrm{LOQ}=0.02$ & $\begin{array}{c}0.482-0.599 \\
0.528\end{array}$ & $<\mathrm{LOQ}=0.1$ & $\begin{array}{c}0.007-0.009 \\
0.008\end{array}$ \\
\hline
\end{tabular}


Table 2. Cont.

\begin{tabular}{|c|c|c|c|c|c|c|}
\hline Parts Used & Botanical Name & $\begin{array}{c}\text { Samples } \\
\text { Analysed }\end{array}$ & $\mathrm{Cd}(\mathrm{mg} / \mathrm{kg})$ & $\mathrm{Pb}(\mathrm{mg} / \mathrm{kg})$ & As (mg/kg) & Hg (mg/kg) \\
\hline & $\begin{array}{l}\text { Bear's garlic } \\
\text { Allium ursinum L. }\end{array}$ & 3 & $\begin{array}{c}0.020-0.040 \\
0.030\end{array}$ & $\begin{array}{l}0.382-0.450 \\
0.416\end{array}$ & $<\mathrm{LOQ}=0.1$ & $\begin{array}{c}0.007-0.009 \\
0.008\end{array}$ \\
\hline \multirow{8}{*}{ Flowers } & $\begin{array}{c}\text { Blackthorn } \\
\text { Prunus spinosa } \mathrm{L} \text {. }\end{array}$ & 3 & $\begin{array}{c}0.049-0.061 \\
0.054\end{array}$ & $\begin{array}{c}1.282-1.421 \\
1.341\end{array}$ & $<\mathrm{LOQ}=0.1$ & $\begin{array}{l}0.006-0.007 \\
0.006\end{array}$ \\
\hline & $\begin{array}{c}\text { Red clover } \\
\text { Trifolium pratense L. }\end{array}$ & 3 & $<\mathrm{LOQ}=0.02$ & $\begin{array}{c}0.322-0.462 \\
0.384\end{array}$ & $<\mathrm{LOQ}=0.1$ & $<\mathrm{LOQ}=0.005$ \\
\hline & $\begin{array}{l}\text { Common heather } \\
\text { Calluna vulgaris L. }\end{array}$ & 3 & $<\mathrm{LOQ}=0.02$ & $\begin{array}{c}0.402-0.502 \\
0.462\end{array}$ & $<\mathrm{LOQ}=0.1$ & $<\mathrm{LOQ}=0.005$ \\
\hline & $\begin{array}{l}\text { Hollyhock } \\
\text { Alcea rosea L. }\end{array}$ & 3 & $\begin{array}{c}0.392-0.552 \\
0.465\end{array}$ & $\begin{array}{c}0.254-0.345 \\
0.299\end{array}$ & $<\mathrm{LOQ}=0.1$ & $<\mathrm{LOQ}=0.005$ \\
\hline & $\begin{array}{c}\text { Camomile } \\
\text { Matricaria chamomilla L. }\end{array}$ & 4 & $\begin{array}{c}0.198-0.244 \\
0.217\end{array}$ & $\begin{array}{l}0.587-2.99 \\
1.572\end{array}$ & $<\mathrm{LOQ}=0.1$ & $<\mathrm{LOQ}=0.005$ \\
\hline & $\begin{array}{l}\text { Common sunflower } \\
\text { Helianthus annuus L. }\end{array}$ & 3 & $<\mathrm{LOQ}=0.02$ & $\begin{array}{c}0.025-0.053 \\
0.034\end{array}$ & $<\mathrm{LOQ}=0.1$ & $<\mathrm{LOQ}=0.005$ \\
\hline & $\begin{array}{l}\text { Small-leaved lime } \\
\text { Tilia cordata Mill. }\end{array}$ & 3 & $\begin{array}{c}0.057-0.077 \\
0.047\end{array}$ & $\begin{array}{l}0.119-0.284 \\
0.207\end{array}$ & $<\mathrm{LOQ}=0.1$ & $<\mathrm{LOQ}=0.005$ \\
\hline & $\begin{array}{l}\text { White nettle } \\
\text { Lamium album L. }\end{array}$ & 3 & $<\mathrm{LOQ}=0.02$ & $\begin{array}{c}0.426-0.585 \\
0.499\end{array}$ & $<\mathrm{LOQ}=0.1$ & $<\mathrm{LOQ}=0.005$ \\
\hline \multirow{4}{*}{ Fruits } & $\begin{array}{c}\text { Dog rose } \\
\text { Rosa canina } \mathrm{L} .\end{array}$ & 3 & $<\mathrm{LOQ}=0.02$ & $<\mathrm{LOQ}=0.01$ & $<\mathrm{LOQ}=0.1$ & $<\mathrm{LOQ}=0.005$ \\
\hline & $\begin{array}{c}\text { Rowan } \\
\text { Sorbus aucuparia L. }\end{array}$ & 4 & $\begin{array}{c}0.030-0.052 \\
0.041\end{array}$ & $\begin{array}{c}0.048-0.062 \\
0.056\end{array}$ & $<\mathrm{LOQ}=0.1$ & $<\mathrm{LOQ}=0.005$ \\
\hline & $\begin{array}{l}\text { Midland hawthorn } \\
\text { Crataegus oxyacantha L. }\end{array}$ & 3 & $\begin{array}{c}<\mathrm{LOQ}=0.02-0.520 \\
0.322\end{array}$ & $\begin{array}{c}0.034-0.295 \\
0.175\end{array}$ & $<\mathrm{LOQ}=0.1$ & $<\mathrm{LOQ}=0.005$ \\
\hline & $\begin{array}{c}\text { Chasteberry } \\
\text { Vitex agnus-castus L. }\end{array}$ & 3 & $<\mathrm{LOQ}=0.02$ & $<\mathrm{LOQ}=0.01$ & $<\mathrm{LOQ}=0.1$ & $<\mathrm{LOQ}=0.005$ \\
\hline \multirow{2}{*}{ Seeds } & $\begin{array}{c}\text { Common flax } \\
\text { Linum usitatissimum L. }\end{array}$ & 24 & $\begin{array}{c}<\mathrm{LOQ}=0.02-0.322 \\
0.137\end{array}$ & $\begin{array}{c}<\mathrm{LOQ}=0.01-0.707 \\
0.089\end{array}$ & $<\mathrm{LOQ}=0.1$ & $<\mathrm{LOQ}=0.005$ \\
\hline & $\begin{array}{l}\text { Narrowleaf plantain } \\
\text { Plantago lanceolata L. }\end{array}$ & 3 & $<\mathrm{LOQ}=0.02$ & $\begin{array}{c}0.025-0.053 \\
0.034\end{array}$ & $<\mathrm{LOQ}=0.1$ & $<\mathrm{LOQ}=0.005$ \\
\hline \multicolumn{7}{|c|}{ Spices } \\
\hline Herbs & $\begin{array}{c}\text { Basil } \\
\text { Ocimum basilicum L. }\end{array}$ & 3 & $<\mathrm{LOQ}=0.02$ & $\begin{array}{c}1.34-1.92 \\
1.66\end{array}$ & $<\mathrm{LOQ}=0.1$ & $<\mathrm{LOQ}=0.005$ \\
\hline \multirow[t]{2}{*}{ Tubers } & $\begin{array}{l}\text { Common onion } \\
\text { Allium cepa L. }\end{array}$ & 3 & $\begin{array}{c}0.036-0.060 \\
0.047\end{array}$ & $\begin{array}{c}0.126-0.305 \\
0.231\end{array}$ & $<\mathrm{LOQ}=0.1$ & $<\mathrm{LOQ}=0.005$ \\
\hline & $\begin{array}{l}\text { Common garlic } \\
\text { Allium sativum L. }\end{array}$ & 3 & $\begin{array}{c}0.029-0.045 \\
0.038\end{array}$ & $\begin{array}{c}0.069-0.092 \\
0.082\end{array}$ & $<\mathrm{LOQ}=0.1$ & $<\mathrm{LOQ}=0.005$ \\
\hline Rhizome & $\begin{array}{c}\text { Turmeric } \\
\text { Curcuma longa } \mathrm{L} .\end{array}$ & 3 & $<\mathrm{LOQ}=0.02$ & $\begin{array}{c}<\mathrm{LOQ}=0.01-0.256 \\
0.138\end{array}$ & $<\mathrm{LOQ}=0.1$ & $<\mathrm{LOQ}=0.005$ \\
\hline \multirow{3}{*}{ Fruits } & $\begin{array}{l}\text { Black pepper } \\
\text { Piper nigrum L. }\end{array}$ & 26 & $\begin{array}{c}<\mathrm{LOQ}=0.02-0.080 \\
0.006\end{array}$ & $\begin{array}{c}<\mathrm{LOQ}=0.01-0.740 \\
0.159\end{array}$ & $\begin{array}{c}<\mathrm{LOQ}=0.1-0.863 \\
0.053\end{array}$ & $<\mathrm{LOQ}=0.005$ \\
\hline & $\begin{array}{c}\text { Peppers } \\
\text { Capsicum annuum L. }\end{array}$ & 8 & $\begin{array}{c}<\mathrm{LOQ}=0.02-0.044 \\
0.002\end{array}$ & $\begin{array}{c}0.070-0.775 \\
0.338\end{array}$ & $\begin{array}{c}<\mathrm{LOQ}= \\
0.01-0.178 \\
0.077\end{array}$ & $<\mathrm{LOQ}=0.005$ \\
\hline & $\begin{array}{c}\text { Allspice } \\
\text { Pimenta dioica } \mathrm{L} .\end{array}$ & 3 & $<\mathrm{LOQ}=0.02$ & $\begin{array}{c}0.309-0.422 \\
0.361\end{array}$ & $<\mathrm{LOQ}=0.1$ & $<\mathrm{LOQ}=0.005$ \\
\hline \multirow{3}{*}{ Seeds } & $\begin{array}{c}\text { Cumin } \\
\text { Cuminum cyminum L. }\end{array}$ & 3 & $\begin{array}{c}0.057-0.082 \\
0.072\end{array}$ & $\begin{array}{c}0.32-0.55 \\
0.43\end{array}$ & $<\mathrm{LOQ}=0.1$ & $<\mathrm{LOQ}=0.005$ \\
\hline & $\begin{array}{c}\text { Fennel } \\
\text { Foeniculum vulgare Mill. }\end{array}$ & 3 & $<\mathrm{LOQ}=0.02$ & $\begin{array}{c}0.253-0.382 \\
0.321 \\
\end{array}$ & $<\mathrm{LOQ}=0.1$ & $<\mathrm{LOQ}=0.005$ \\
\hline & $\begin{array}{c}\text { Fenugreek } \\
\text { Trigonella } \\
\text { foenum-graecum L. }\end{array}$ & 3 & $\begin{array}{c}0.026-0.041 \\
0.034\end{array}$ & $\begin{array}{c}0.159-0.202 \\
0.173\end{array}$ & $<\mathrm{LOQ}=0.1$ & $<\mathrm{LOQ}=0.005$ \\
\hline
\end{tabular}


Table 2. Cont.

\begin{tabular}{|c|c|c|c|c|c|c|}
\hline Parts Used & Botanical Name & $\begin{array}{l}\text { Samples } \\
\text { Analysed }\end{array}$ & $\mathrm{Cd}(\mathrm{mg} / \mathrm{kg})$ & $\mathrm{Pb}(\mathrm{mg} / \mathrm{kg})$ & As (mg/kg) & $\mathrm{Hg}(\mathrm{mg} / \mathrm{kg})$ \\
\hline Flowers & $\begin{array}{c}\text { Clove tree } \\
\text { Eugenia caryophyllus L. }\end{array}$ & 3 & $<\mathrm{LOQ}=0.02$ & $\begin{array}{c}0.254-0.422 \\
0.343\end{array}$ & $<\mathrm{LOQ}=0.1$ & $<\mathrm{LOQ}=0.005$ \\
\hline \multicolumn{7}{|c|}{ Tea and Coffee } \\
\hline & Leaf of China tea & 8 & $\begin{array}{c}0.069-0.098 \\
0.034\end{array}$ & $\begin{array}{c}<\mathrm{LOQ}=0.01-0.150 \\
0.070\end{array}$ & $<\mathrm{LOQ}=0.1$ & $\begin{array}{c}<\mathrm{LOQ}=0.005-0.007 \\
0.006\end{array}$ \\
\hline & Beans of Arabica coffee & 8 & $\begin{array}{c}<\mathrm{LOQ}=0.02-0.088 \\
0.058\end{array}$ & $\begin{array}{l}0.021-0.791 \\
0.140\end{array}$ & $<\mathrm{LOQ}=0.1$ & $\begin{array}{c}<\mathrm{LOQ}=0.005-0.007 \\
0.006\end{array}$ \\
\hline
\end{tabular}

The scope of the presented study also included the estimation of cadmium concentration in 61 samples of spices used in Poland. The level of contamination of the analysed samples with cadmium was low and varied from $<\mathrm{LOQ}(0.020 \mathrm{mg} / \mathrm{kg})$ to $0.082 \mathrm{mg} / \mathrm{kg}$. None of the analysed samples contained cadmium levels exceeding the permitted limits for that metal. In all analysed samples of five species of spices (green matter of basil, turmeric, fruit of allspice, seeds of fennel, and flowers of clove tree), no contamination with cadmium was noted. The highest average concentrations of cadmium were noted in samples of black pepper and seeds of cumin, at 0.080 and $0.082 \mathrm{mg} / \mathrm{kg}$, respectively.

Another group of samples analysed within the scope of this study for the level of contamination with cadmium included eight samples of leaves of China tea and eight samples of Arabica coffee beans. The analyses revealed low levels of that element in the samples, within the range from $<\mathrm{LOQ}(0.020 \mathrm{mg} / \mathrm{kg})$ to $0.098 \mathrm{mg} / \mathrm{kg}$.

The results obtained in this study are comparable to most of the results published in the literature. The authors of the cited publications obtained similar levels of cadmium in samples of herbs and spices analysed in Poland. Mirosławski and Pakuszto [26] analysed herbs (leaf of peppermint and flower of camomile) available on the Polish market and found average levels of cadmium varying from $0.180 \mathrm{mg} / \mathrm{kg}$ to $0.730 \mathrm{mg} / \mathrm{kg}$. Similar results concerning the level of heavy metals in selected Polish herbs and spices (green matter of basil, root of curcuma, flower buds of clove tree, fruit of black pepper and peppers, onion, bear's garlic, and allspice) were obtained by Krejpcio et al. [27], who reported that the average content of cadmium varied within the range from 0.010 to $0.140 \mathrm{mg} / \mathrm{kg}$. Gajewska et al. [28] analysed herbal plants and spices available on the retail market in Poland and demonstrated average cadmium levels of $0.011-0.879 \mathrm{mg} / \mathrm{kg}$. Low levels of cadmium in samples of spices available in Poland were confirmed in a study by Staniek and Krejpcio [29], who reported that the accumulation of cadmium in samples of peppers and black pepper varied from 0.015 to $0.017 \mathrm{mg} / \mathrm{kg}$. Fischer et al. [30] analysed spice plants grown in Poland and noted cadmium concentrations within the range from 0.02 to $1.94 \mathrm{mg} / \mathrm{kg}$.

The presented results correspond with analyses of samples of herbs and spices conducted in other European countries. A monitoring study on the content of heavy metals conducted in Austria [31] demonstrated that the level of cadmium in herbs and spices was at levels from $0.02 \mathrm{mg} / \mathrm{kg}$ in samples of green matter of lemon balm and common yarrow to $0.98 \mathrm{mg} / \mathrm{kg}$ in green matter of St John's wort. Reinholds et al. [32] analysed herbs and spices and noted diversified levels of cadmium dependent on the plant species. They demonstrated the highest accumulation of cadmium in samples of green matter of common thyme and basil, at $0.400 \mathrm{mg} / \mathrm{kg}$ and $0.120 \mathrm{mg} / \mathrm{kg}$, respectively, while the lowest levels of that element were noted in samples of black pepper and wild marjoram- $0.010 \mathrm{mg} / \mathrm{kg}$ and $0.020 \mathrm{mg} / \mathrm{kg}$, respectively.

Analyses of herbal raw materials from other regions of the world show similar results to those obtained in the presented study. Literature data from Turkey concerning the study of the levels of heavy metals reported cadmium contamination of samples of herbs and spices (green matter of common sage, basil, common thyme, lemon balm, flower of smallleaved lime and camomile, fruit of midland hawthorn and dog rose, and seeds of fennel) 
in the range from $0.010 \mathrm{mg} / \mathrm{kg}$ to $2.700 \mathrm{mg} / \mathrm{kg}$ [33-35]. Studies on the content of heavy metals conducted in Iran and Iraq noted cadmium levels in analysed samples of herbal plants and spices in the range from $0.012 \mathrm{mg} / \mathrm{kg}$ in samples of curcuma to $1.64 \mathrm{mg} / \mathrm{kg}$ in samples of dill [36-38]. In the United Arab Emirates, Dghaim et al. [39] analysed seven species of herbal plants (parsley, basil, common sage, oregano, mint, common thyme, and camomile) and demonstrated average levels of cadmium in the range from less than $0.1 \mathrm{mg} / \mathrm{kg}$ in green matter of mint to $1.11 \mathrm{mg} / \mathrm{kg}$ in green matter of basil. Dghaim et al. [39] also demonstrated that $55 \%$ of samples of camomile inflorescences contained cadmium $(0.82 \mathrm{mg} / \mathrm{kg})$ in excess of the highest permissible level $(0.3 \mathrm{mg} / \mathrm{kg})$, which was never found in the results presented in this study. In selected studies on the accumulation of cadmium in samples of herbal plants and spices, decidedly higher levels of cadmium content were noted, in the range of $0.23 \mathrm{mg} / \mathrm{kg}$ to $23.1 \mathrm{mg} / \mathrm{kg}$ [40-42], considerably exceeding the WHO limits for that metal, which was not shown in the presented results of our study.

The results obtained in this study, indicating low levels of cadmium in samples of tea, are in support of earlier studies in this area. Wojciechowska and Mazurek [43] analysed Indian teas available on the Polish market and found average cadmium levels of $0.034 \mathrm{mg} / \mathrm{kg}$ in samples of leaf tea and $0.026 \mathrm{mg} / \mathrm{kg}$ in samples of tea bags. Another study, focusing on the analysis of herbal teas produced in Poland, indicated contamination with that metal in the range of $0.024-0.153 \mathrm{mg} / \mathrm{kg}$ [44]. Winiarska-Mieczan et al. [45] also analysed Polish herbal teas and noted an average cadmium level of $0.2 \mathrm{mg} / \mathrm{kg}$. Studies on the accumulation of cadmium in various kinds of tea, conducted by Sarojama [46] and by Zhong et al. [47], revealed contamination of the analysed samples at levels from $0.021 \mathrm{mg} / \mathrm{kg}$ to $0.064 \mathrm{mg} / \mathrm{kg}$ and from $0.010 \mathrm{mg} / \mathrm{kg}$ to $0.390 \mathrm{mg} / \mathrm{kg}$, respectively. The lowest level of cadmium was noted in black tea, while the highest level was assayed in Pu'erh tea. The content of cadmium in samples of green tea varied from 0.040 to $0.110 \mathrm{mg} / \mathrm{kg}$ [47]. Basgel and Erdemoglu [48] analysed herbal teas and demonstrated cadmium levels in the range from $0.004 \mathrm{mg} / \mathrm{kg}$ for dill tea to $0.440 \mathrm{mg} / \mathrm{kg}$ for camomile tea. Certain literature reports highlighted decidedly higher levels of cadmium contamination of tea samples, i.e., from $16.7 \mathrm{mg} / \mathrm{kg}$ to $69.85 \mathrm{mg} / \mathrm{kg}$ [49], which are not in line with the presented research results.

The low levels of cadmium contamination of samples of coffee noted in the presented study correspond with the results of a Polish study by Adler et al. [50], who analysed samples of coffee and demonstrated that the content of cadmium varied from $0.014 \mathrm{mg} / \mathrm{kg}$ to $0.015 \mathrm{mg} / \mathrm{kg}$ in green coffee beans and from $0.011 \mathrm{mg} / \mathrm{kg}$ to $0.022 \mathrm{mg} / \mathrm{kg}$ in roasted beans of coffee. Długaszek et al. [51] analysed the content of cadmium in Colombian coffee purchased in Poland and noted its accumulation at a level similar to that observed in the presented study. Similar results of cadmium content, within the range from $0.025 \mathrm{mg} / \mathrm{kg}$ to $0.100 \mathrm{mg} / \mathrm{kg}$, were obtained in a study on Brazilian coffee [52]. In a study by Grembecka et al. [53], cadmium content in roasted coffee beans from Africa, America, Asia, and Oceania oscillated below the level of detection.

\subsection{Lead}

In the analysed samplers of herbs, the level of lead was diversified in relation to the species and varied within the range from <LOQ $(0.010 \mathrm{mg} / \mathrm{kg})$ to $5.680 \mathrm{mg} / \mathrm{kg}$. The content of lead was not in excess of the limit value set by the World Health Organisation (WHO) at the level of $10 \mathrm{mg} / \mathrm{kg}$ in any of the analysed samples of herbs. Among the 163 analysed samples, no presence of lead was detected (green matter of common thyme and field horsetail, leaf of globe artichoke, and fruit of chasteberry) in only 12 samples $(7 \%)$. The lowest average levels of lead, ranging from $0.022 \mathrm{mg} / \mathrm{kg}$ to $0.201 \mathrm{mg} / \mathrm{kg}$, were noted in samples of seven herbal species-green matter of common oat, root of common chicory, leaf of white mulberry, flower of common sunflower, fruit of rowan, and seeds of common flax and narrowleaf plantain. The highest levels of contamination with lead were noted in samples of root of valerian and green matter of lemon balm and common sage, at $5.680 \mathrm{mg} / \mathrm{kg}, 3.47 \mathrm{mg} / \mathrm{kg}$, and $2.550 \mathrm{mg} / \mathrm{kg}$, respectively. 
Analysis of the content of lead in 61 samples of spices available on the Polish market demonstrated diversified levels of the analysed metal, in relation to the plant species $(<\mathrm{LOQ}=0.010-1.92 \mathrm{mg} / \mathrm{kg})$. In $97 \%$ of the analysed samples of spices, contamination with lead was noted; however, the assayed levels of lead were not in excess of the permissible limits for this metal in any of the samples. The lowest lead content, ranging from 0.069 to $0.202 \mathrm{mg} / \mathrm{kg}$, was noted in samples of four herbal species-bear's garlic, black pepper, peppers, and fenugreek. The highest concentration of lead, at the level of $1.92 \mathrm{mg} / \mathrm{kg}$, was assayed in samples of green matter of basil.

Analyses of lead contamination of samples of leaves of Chinese tea and beans of Arabica coffee presented in this study demonstrated low levels of the metal in the analysed samples, ranging from less than $0.010 \mathrm{mg} / \mathrm{kg}$ to $0.791 \mathrm{mg} / \mathrm{kg}$.

The results obtained in this study, concerning lead contamination of samples of herbs and spices, correspond with earlier studies on this subject matter, conducted in Poland. Mirosławski and Pakuszto [26] analysed herbs (leaf of peppermint and flower of camomile) available on the Polish market and noted average levels of lead in the range of $0.440 \mathrm{mg} / \mathrm{kg}$ $1.110 \mathrm{mg} / \mathrm{kg}$. Similar results concerning the levels of $\mathrm{Pb}$ in selected Polish herbs and spices (green matter of basil, root of curcuma, flower buds of clove tree, fruits of black pepper and peppers, onion, bear's garlic, and allspice) were obtained by Krejpcio et al. [27], who reported that the average content of lead varied in the range from $0.250 \mathrm{mg} / \mathrm{kg}$ to $1.490 \mathrm{mg} / \mathrm{kg}$. Gajewska et al. [28], in a study on herbal plants and spices available on the retail market in Poland, demonstrated average levels of lead in the range of $0.020 \mathrm{mg} / \mathrm{kg}$ $2.25 \mathrm{mg} / \mathrm{kg}$. The low levels of lead in samples of spices available in Poland find support in a study by Staniek and Krejpcio [29], who reported that the accumulation of lead in samples of peppers and black pepper varied in the range from 0.044 to $0.377 \mathrm{mg} / \mathrm{kg}$.

The presented results correspond also with analyses of herbal and spice samples conducted in other European countries, e.g., in Serbia [54], in which the concentration of lead in samples of black pepper varied within the range from $0.280 \mathrm{mg} / \mathrm{kg}$ to $0.42 \mathrm{mg} / \mathrm{kg}$. A monitoring study concerning the level of heavy metals in products in Austria [31] demonstrated that the level of lead in herbs and spices varied within the range from $0.2 \mathrm{mg} / \mathrm{kg}$ in samples of the fruit of caraway to $1.9 \mathrm{mg} / \mathrm{kg}$ in leaves of lovage. Reinholds et al. [32] analysed herbs and spices and noted diversified levels of lead, depending on the plant species. They assayed the highest accumulation of lead in samples of green matter of common thyme and basil, at $0.790 \mathrm{mg} / \mathrm{kg}$ and $0.480 \mathrm{mg} / \mathrm{kg}$, respectively, and the lowest in samples of nutmeg, black pepper, and oregano, from $0.130 \mathrm{mg} / \mathrm{kg}$ to $0.280 \mathrm{mg} / \mathrm{kg}$, respectively. Furthermore, in our study the highest concentration of lead was assayed in samples of green matter of basil, while the lowest levels of this metal were noted in samples of black pepper. Literature data from Turkey, concerning the levels of heavy metals, report a similar level of lead contamination of samples of herbs and spices (green matter of common sage, basil, common thyme, lemon balm, flower of small-leaved lime, and camomile, fruit of midland hawthorn and dog rose, and seeds of fennel), ranging from $0.1 \mathrm{mg} / \mathrm{kg}$ to $4.43 \mathrm{mg} / \mathrm{kg}$ [33-35].

Numerous literature reports, however, indicated significantly higher levels of lead contamination of analysed samples of herbal raw materials and spices, exceeding the maximum allowable levels set for this metal by the WHO-10 mg/kg [10], which was not demonstrated in the presented study. Notably higher concentrations of lead were presented in a study by Huremović et al. [55], covering six species of spices (black pepper, basil, oregano, peppers, parsley, and rosemary), in which the concentration of the metal varied from $0.740 \mathrm{mg} / \mathrm{kg}$ to $20.35 \mathrm{mg} / \mathrm{kg}$. In the study by Huremović et al. [55], nearly $67 \%$ of the analysed samples had lead levels exceeding the maximum allowable value for that metal $(10 \mathrm{mg} / \mathrm{kg})$, which was not noted in the results of the presented study. Analysis of the content of heavy metals in herbs and spices, conducted in Iran and Iraq, revealed lead contamination in the analysed samples at levels from $0.15 \mathrm{mg} / \mathrm{kg}$ in samples of chasteberry to $14.6 \mathrm{mg} / \mathrm{kg}$ in samples of fenugreek [37,38]. Dghaim et al. [39] analysed seven herbal plant species consumed in the United Arab Emirates (parsley, basil, common 
sage, oregano, mint, common thyme, and camomile) and noted average lead levels from less than $1.0 \mathrm{mg} / \mathrm{kg}$ in green matter of mint to $23.52 \mathrm{mg} / \mathrm{kg}$ in green matter of common thyme. Dghaim et al. [39] also demonstrated that $44 \%$ of camomile samples and $100 \%$ of samples of common sage contained lead at concentrations exceeding the maximum allowable level, which differs considerably from the results obtained in this study. High levels of lead in samples of herbs and spices, considerably in excess of the limits set by the WHO for this metal, were also demonstrated in studies conducted in Jordan $(0.2-41.18 \mathrm{mg} / \mathrm{kg})$, Punjab (3.21-28.7 mg/kg), and India (13.0-54.47 mg/kg) [41,42,56]. Studies on herbal raw materials from various regions of the world have indicated that the content of heavy metals in herbal and spice plants depends on numerous factors, such as the region of their origin, the level of environmental contamination, the plant species, and the technological process.

The results of this study, concerning low levels of lead in samples of leaves of Chinese tea, find support in earlier studies published in the area of this subject matter. Wojciechowska and Mazurek [43] analysed Indian teas available on the Polish market and noted average lead levels of $0.36 \mathrm{mg} / \mathrm{kg}$ in samples of leaf tea and $0.29 \mathrm{mg} / \mathrm{kg}$ in samples of tea bags. In Poland, Brzezicha-Cirocka et al. [3], as well as Gutt et al. [57], also demonstrated low levels of contamination with the analysed metal in samples of green, black, herbal, and fruit teas. Another study aimed at the analysis of the content of lead in herbal teas produced in Poland demonstrated a similar level of contamination of analysed samples with that element, ranging from 0.44 to $0.77 \mathrm{mg} / \mathrm{kg}$ [44].

Literature reports from other parts of the world correspond with the results presented earlier. In a study conducted by Zhong et al. [47], the level of lead in various kinds of Chinese teas varied from $0.48 \mathrm{mg} / \mathrm{kg}$ (in samples of jasmine tea) to $10.57 \mathrm{mg} / \mathrm{kg}$ (in samples of green tea). Othman et al. [58] noted average concentrations of lead in green tea products imported from China ranging from $0.231 \mathrm{mg} / \mathrm{kg}$ to $4.460 \mathrm{mg} / \mathrm{kg}$. Similarly, Basgel and Erdemoglu [48], in a study on herbal teas, demonstrated lead levels within the range from $0.26 \mathrm{mg} / \mathrm{kg}$ in the case of inflorescences of small-leaved lime to $4.80 \mathrm{mg} / \mathrm{kg}$ in samples of nettle leaves. Those values did not exceed the permissible limits for that metal, and they correspond with the results obtained in the presented study.

The low level of lead contamination of coffee bean samples in the results of the presented study correspond with those obtained in another Polish study, conducted by Adler et al. [50], who demonstrated low levels of concentration of that metal, from $0.008 \mathrm{mg} / \mathrm{kg}$ to $0.144 \mathrm{mg} / \mathrm{kg}$ in green coffee beans and from $0.013-0.022 \mathrm{mg} / \mathrm{kg}$ in roasted coffee beans. Długaszek et al. [51] estimated the content of lead in Colombian coffee purchased in Poland and noted an accumulation of that metal at levels from $0.020 \mathrm{mg} / \mathrm{kg}$ to $0.060 \mathrm{mg} / \mathrm{kg}$. Similar results concerning the content of lead, ranging from $0.075 \mathrm{mg} / \mathrm{kg}$ to $1.575 \mathrm{mg} / \mathrm{kg}$, were noted in a study on Brazilian coffee [52].

\subsection{Arsenic}

Among the 163 analysed samples of herbs, the presence of arsenic was found only in 12 samples (7\%) - in nine samples of the root of valerian $(0.111-0.535 \mathrm{mg} / \mathrm{kg})$ and in three samples of leaves of blackcurrant $(0.166-0.202 \mathrm{mg} / \mathrm{kg})$. In the remaining $93 \%$ of the analysed samples of herbs, the concentration of arsenic was below the threshold of detection $(0.1 \mathrm{mg} / \mathrm{kg})$. In the group of 61 analysed samples of spices, arsenic was detected only in five samples of black pepper $(0.102-0.863 \mathrm{mg} / \mathrm{kg})$ and in four samples of peppers $(0.113-0.178 \mathrm{mg} / \mathrm{kg})$. In all of the analysed samples of coffee beans and tea leaves, the assayed content of the metal in question was below the threshold of detection.

Literature data covering studies in the area of contamination with arsenic support the results obtained in this study. In a study on herbal raw materials, conducted by Alhusbaba et al. [56], no arsenic contamination was demonstrated in any of the 40 analysed samples. Reinholds et al. [32] analysed herbs and spices in the aspect of arsenic contamination of samples and found low average levels of the metal, ranging from $0.03 \mathrm{mg} / \mathrm{kg}$ and $0.06 \mathrm{mg} / \mathrm{kg}$ in samples of nutmeg and black pepper to $0.37 \mathrm{mg} / \mathrm{kg}$ in samples of oregano. A similar level of contamination with arsenic, with an average of $0.053 \mathrm{mg} / \mathrm{kg}$ in samples of 
black pepper, was obtained in the presented study. An Indian study monitoring the content of arsenic in samples of herbal raw materials revealed concentrations of the analysed metal that ranged from below the threshold of detection in samples of long pepper $(0.050 \mathrm{mg} / \mathrm{kg})$ to $0.52 \mathrm{mg} / \mathrm{kg}$ in samples of ginger [59].

The results obtained in the presented study, concerning the level of contamination with arsenic, find support in a Malaysian study on herbs and spices commonly consumed in that country [40], in which the levels of the analysed metal varied in the range from $0.24 \mathrm{mg} / \mathrm{kg}$ in samples of bear's garlic to $2.54 \mathrm{mg} / \mathrm{kg}$ in Philippine flower wax. Similar results of arsenic contamination were presented in a study involving the analysis of various samples of black pepper available on the Serbian market, in which arsenic was assayed in the range from $0.22 \mathrm{mg} / \mathrm{kg}$ in samples of green pepper to $0.51 \mathrm{mg} / \mathrm{kg}$ in samples of black pepper [54]. Higher levels of contamination of herbal raw materials were reported in studies conducted in Turkey [34] and Iran [36], in which the concentration of arsenic varied from $0.20 \mathrm{mg} / \mathrm{kg}$ in samples of dog rose to $19.4 \mathrm{mg} / \mathrm{kg}$ in samples of aniseed.

In contrast to our study, in which no detectable residues of the analysed metal were found in samples of tea leaves and coffee beans, a study conducted by Mania et al. [59] on various kinds of tea available on the Polish market indicated that the content of arsenic varied in the range from $0.085 \mathrm{mg} / \mathrm{kg}$ in samples of black tea to $0.134 \mathrm{mg} / \mathrm{kg}$ in samples of green tea. The level of arsenic contamination in the presented research results $(<\mathrm{LOQ}=0.1 \mathrm{mg} / \mathrm{kg})$ was similar to that obtained in Poland [60] and in other EU countries $(0.066 \mathrm{mg} / \mathrm{kg})[61]$, but significantly lower than the results obtained in studies conducted in Asia, in which the content of arsenic in various kinds of tea varied in the range from below the threshold of detection to $4.81 \mathrm{mg} / \mathrm{kg}$ [62-64].

\subsection{Mercury}

The concentration of mercury in the analysed samples of herbs varied in the range from below the threshold of detection $(0.005 \mathrm{mg} / \mathrm{kg})$ to $0.030 \mathrm{mg} / \mathrm{kg}$. The presence of mercury was demonstrated in 45 of the analysed samples of herbs (28\%), while, in $72 \%$ of the analysed samples, the content of mercury was below the threshold of detection equal to $0.005 \mathrm{mg} / \mathrm{kg}$. The lowest content of mercury, at the level of $0.006 \mathrm{mg} / \mathrm{kg}$, was noted in samples of six species of herbs-common mugwort, smallflower hairy willowherb, valerian, marshmallow, common chicory, and blackthorn. The highest levels of contamination with mercury were demonstrated in samples of green matter of field horsetail and in leaves of European blueberry, at $0.020 \mathrm{mg} / \mathrm{kg}$ and $0.030 \mathrm{mg} / \mathrm{kg}$, respectively. In all 61 analysed samples of spices, the level of contamination with mercury was below the threshold of detection. In the group of analysed samples of tea leaves and coffee beans, trace levels of mercury were assayed, in the range from below $0.005 \mathrm{mg} / \mathrm{kg}$ to $0.007 \mathrm{mg} / \mathrm{kg}$.

In the area of contamination of samples of herbal raw materials with mercury, the results of the presented study correspond with the results obtained by Fischer et al. [65], who analysed the level of contamination of selected herbs grown in Poland and demonstrated levels of the analysed metal in the range from $0.005 \mathrm{mg} / \mathrm{kg}$ in samples of green matter of St. John's wort to $0.025 \mathrm{mg} / \mathrm{kg}$ in samples of nettle leaves. Mercury contents at levels from below $0.005 \mathrm{mg} / \mathrm{kg}$ to $0.020 \mathrm{mg} / \mathrm{kg}$ were also noted by Kowalski and Kucharski [66] in a study on herbal raw materials available on the Polish market. An Asian study on over a dozen herbal raw materials popular in Korea also revealed an absence of contamination with mercury in $100 \%$ of the analysed samples of herbs [67]. Similar results in this respect were presented in a study on herbal samples, conducted in India, in which no contamination with mercury was assayed in $90 \%$ of analysed samples, with the exception of one sample of liquorice, in which the level of mercury was $0.060 \mathrm{mg} / \mathrm{kg}$ [59].

The low levels of mercury in the analysed samples of spices find support in a Serbian study on various kinds of pepper [54], in which the level of contamination of samples with the analysed metal was $0.103 \mathrm{mg} / \mathrm{kg}$ in samples of green pepper, while, in the remaining samples of black and white pepper, contamination with mercury was below the threshold of detection $(0.003 \mathrm{mg} / \mathrm{kg})$. In an Indian study, no contamination with mercury was noted 
in all analysed samples of black pepper, curcuma, and cumin [41], which is in line with the results obtained in the presented study.

Selected literature reports concerning the level of contamination of samples of herbal raw materials with heavy metals presented higher levels of mercury in analysed samples. In a study on spices and herbs commonly consumed in Malaysia [40], the authors noted mercury contamination levels in the range from $0.06 \mathrm{mg} / \mathrm{kg}$ in samples of leaves of kaffir lime to $0.52 \mathrm{mg} / \mathrm{kg}$ in a sample of ginger. The differences in the levels of contamination of samples of herbs and spices with heavy metals reflect the great diversity in the level of contamination of local environments with the analysed metals (in this case, mercury).

The trace amounts of mercury in samples of tea leaves and coffee beans reported in the presented study are in support of an earlier study conducted in this field by Kowalski et al. [13]. Among 81 analysed samples of fruit teas, teas regulating digestion, green teas, black teas, and Pu'erh type teas, the presence of mercury was assayed at a level above $0.02 \mathrm{mg} / \mathrm{kg}$ in only one sample. The cited authors demonstrated the highest concentration of mercury in one sample of a single-component fruit tea $(0.031 \mathrm{mg} / \mathrm{kg})$. In the case of green teas, the highest concentration of mercury was $0.007 \mathrm{mg} / \mathrm{kg}$, and, in the case of black teas, the maximum assayed level of mercury was $0.009 \mathrm{mg} / \mathrm{kg}$. WojciechowskaMazurek et al. [43] reported that the average contamination of leaf teas, tea bags, granulated teas, and fruit teas was $0.008 \mathrm{mg} / \mathrm{kg}, 0.007 \mathrm{mg} / \mathrm{kg}, 0.009 \mathrm{mg} / \mathrm{kg}$, and $0.003 \mathrm{mg} / \mathrm{kg}$, respectively, which is generally in line with the presented study. Similar results concerning the contamination of samples of leaf tea with mercury, at the level of $0.005 \mathrm{mg} / \mathrm{kg}$, were reported by Forsberg and McQuatters [68]. A study conducted by the Canadian Food Inspection Agency in the area of the content of mercury in samples of tea revealed that $53 \%$ of the analysed samples had no detectable residues of mercury, while, in the remaining $47 \%$ of the analysed samples, the highest assayed concentration of mercury was $0.023 \mathrm{mg} / \mathrm{kg}$ [69].

\subsection{Health Risk Assessment (Noncarcinogenic Risk)}

The THQ rank order of heavy metals in spices was $\mathrm{As}>\mathrm{Cd}>\mathrm{Pb}>\mathrm{Hg}$ (Table 3). In the case of herbs, the THQ was characterised by higher values compared to spices for $\mathrm{Pb}, \mathrm{Hg}$, and $\mathrm{Cd}$, while, in the case of $\mathrm{As}$, the value was lower, i.e., $\mathrm{Cd}>\mathrm{As}>\mathrm{Pb}>\mathrm{Hg}$. The values of THQ for leaves of Chinese tea could be ranked as follows: $\mathrm{Cd}>\mathrm{Pb}>\mathrm{Hg}>$ As. The series of values of THQ calculated for roasted coffee beans were as follows: $\mathrm{Cd}>\mathrm{Pb}>\mathrm{Hg}>\mathrm{As}$.

As the concentration of $\mathrm{Cd}$ was generally fairly high, relative to the other toxic elements (Table 2), and its RfD value was also relatively low $(0.001 \mathrm{mg} / \mathrm{kg} /$ day) [22], the THQ value for $\mathrm{Cd}$ was higher than that for the other monitored levels of elements. The values of TTHQmax (in relation to the consumption of the analysed products) were up to $4.23 \times 10^{-2}$ for spices, up to $2.51 \times 10^{-1}$ for herbs, up to $4.03 \times 10^{-2}$ for Chinese leaf tea, and up to $1.25 \times 10^{-1}$ for roasted coffee beans (Table 2). Since the value of $\mathrm{THQ} \leq 1$, there was no probability of occurrence of unfavourable effects [15]. According to the available literature data, THQ values for heavy metals in herbs, spices, tea, and coffee were considerably lower than 1 . As an example, in a study conducted in Iran, the calculated values of THQ related to the consumption of herbs were as follows: in the case of $\mathrm{Cd}$ - up to $1.50 \times 10^{-2}$, in the case of $\mathrm{Pb}$-in the range up to $1.60 \times 10^{-2}$ [36]; in another study, the values were as follows: in the case of Cd-up to $1.49 \times 10^{-1}$, As-up to $8.40 \times 10^{-2}, \mathrm{~Pb}-$ up to $3.00 \times 10^{-2}, \mathrm{Hg}-7.00 \times 10^{-3}$ [36]. Similarly low values of THQ were obtained by authors of other studies. In Egypt, in a study on spices, the values for As were up to $7.50 \times 10^{-2}$ [70]; in a study conducted in Ethiopia, the values obtained for $\mathrm{Pb}$ were up to $30.75 \times 10^{-2}$ [71]; in a study on herbal products, conducted in Ghana, the following values of THQ were obtained: in the case of As-up to $8.28 \times 10^{-2}$, for $\mathrm{Cd}-\mathrm{up}$ to 0.0015 , for $\mathrm{Pb}$ - up to 0.0034 , and for $\mathrm{Hg}$ - up to 0.0001 [72]. In another study conducted in Ghana, the values of THQ in the case of absorption of heavy metals related with the consumption of tea were as follows: for $\mathrm{As}-\mathrm{up}$ to 0.89 , for $\mathrm{Pb}-\mathrm{up}$ to 0.0109 , and for $\mathrm{Cd}$-up to $2.00 \times 10^{-1}$ [73]. Total target hazard quotient (TTHQ) values for all samples of spices analysed in Nigeria fell within the range of $6.00 \times 10^{-2}-5.00 \times 10^{-1}$ [74]. On the 
other hand, THQ values determined for metals analysed in a study conducted in China were as follows: for $\mathrm{Pb}-$ up to $1.24 \times 10^{-2}, \mathrm{Cd}-$ up to $1.20 \times 10^{-2}$, As-up to $4.53 \times 10^{-2}$, and $\mathrm{Hg}-$ up to $6.00 \times 10^{-2}$ [75]. In a Polish study, THQ values related to the consumption of coffee were up to $2.33 \times 10^{-1}$ and up to $6.70 \times 10^{-2}$ for $\mathrm{Pb}$ and $\mathrm{Cd}$, respectively [76].

Table 3. The health risk assessment related with the consumption of investigated products.

\begin{tabular}{|c|c|c|c|c|}
\hline & $\mathbf{P b}$ & $\mathrm{Hg}$ & $\mathrm{Cd}$ & As \\
\hline \multicolumn{5}{|c|}{ * THQ } \\
\hline Spices (mean) & $1.07 \times 10^{-3}$ & 0 & $1.80 \times 10^{-3}$ & $4.33 \times 10^{-3}$ \\
\hline Spices (max) & $5.33 \times 10^{-3}$ & 0 & $8.20 \times 10^{-3}$ & $2.88 \times 10^{-2}$ \\
\hline Herbs (mean) & $1.41 \times 10^{-3}$ & $1.00 \times 10^{-4}$ & $1.94 \times 10^{-2}$ & $2.70 \times 10^{-4}$ \\
\hline Herbs (max) & $1.58 \times 10^{-2}$ & $6.70 \times 10^{-4}$ & $2.17 \times 10^{-1}$ & $1.78 \times 10^{-2}$ \\
\hline Tea (mean) & $7.50 \times 10^{-4}$ & $7.70 \times 10^{-4}$ & $1.31 \times 10^{-2}$ & 0 \\
\hline Tea (max) & $1.61 \times 10^{-3}$ & $9.00 \times 10^{-4}$ & $3.78 \times 10^{-2}$ & 0 \\
\hline Coffee (mean) & $4.33 \times 10^{-3}$ & $1.11 \times 10^{-3}$ & $6.46 \times 10^{-2}$ & 0 \\
\hline Coffee (max) & $2.45 \times 10^{-2}$ & $2.60 \times 10^{-3}$ & $9.81 \times 10^{-2}$ & 0 \\
\hline \multicolumn{5}{|c|}{ ** TTHQ } \\
\hline Spices (mean) & \multicolumn{4}{|c|}{$7.20 \times 10^{-3}$} \\
\hline Spices (max) & \multicolumn{4}{|c|}{$4.23 \times 10^{-2}$} \\
\hline Herbs (mean) & \multicolumn{4}{|c|}{$2.12 \times 10^{-2}$} \\
\hline Herbs (max) & \multicolumn{4}{|c|}{$2.51 \times 10^{-1}$} \\
\hline Tea (mean) & \multicolumn{4}{|c|}{$1.46 \times 10^{-2}$} \\
\hline Tea (max) & \multicolumn{4}{|c|}{$4.03 \times 10^{-2}$} \\
\hline Coffee (mean) & \multicolumn{4}{|c|}{$7.01 \times 10^{-2}$} \\
\hline Coffee (max) & \multicolumn{4}{|c|}{$1.25 \times 10^{-1}$} \\
\hline \multicolumn{5}{|c|}{$* * *$ EDI } \\
\hline Spices (mean) & $3.85 \times 10^{-3}$ & 0 & $1.80 \times 10^{-4}$ & $1.30 \times 10^{-3}$ \\
\hline Spices (max) & $1.92 \times 10^{-2}$ & 0 & $8.20 \times 10^{-4}$ & $8.63 \times 10^{-3}$ \\
\hline Herbs (mean) & $5.08 \times 10^{-3}$ & $3.00 \times 10^{-5}$ & $1.94 \times 10^{-3}$ & $8.00 \times 10^{-5}$ \\
\hline Herbs (max) & $5.68 \times 10^{-2}$ & $2.00 \times 10^{-4}$ & $2.17 \times 10^{-2}$ & $5.35 \times 10^{-3}$ \\
\hline Tea (mean) & $2.70 \times 10^{-3}$ & $2.30 \times 10^{-4}$ & $1.31 \times 10^{-3}$ & 0 \\
\hline Tea $(\max )$ & $5.79 \times 10^{-3}$ & $2.70 \times 10^{-4}$ & $3.78 \times 10^{-3}$ & 0 \\
\hline Coffee (mean) & $1.56 \times 10^{-2}$ & $3.30 \times 10^{-4}$ & $6.46 \times 10^{-3}$ & 0 \\
\hline Coffee (max) & $8.81 \times 10^{-2}$ & $7.80 \times 10^{-4}$ & $9.81 \times 10^{-3}$ & 0 \\
\hline
\end{tabular}

CR values of As were from 0 (tea and coffee mean value of As) to $1.95 \times 10^{-6}$ (spices mean value of As) and from 0 (tea and coffee max. value of As) to $1.29 \times 10^{-5}$ (spices max. value of As) (Table 4). All values determined for the carcinogenic risk were at the level lower than the maximum acceptable level of $1.0 \times 10^{-4}$, which indicates no significant influence on this risk according to the United States Environmental Protection Agency (USEPA).

Table 4. The carcinogenic risk (CR) assessment related with the consumption of investigated products.

\begin{tabular}{cc}
\hline & CR \\
\hline Spices (mean) & $1.95 \times 10^{-6}$ \\
Spices (max) & $1.29 \times 10^{-5}$ \\
Herbs (mean) & $1.20 \times 10^{-7}$ \\
Herbs (max) & $8.03 \times 10^{-6}$ \\
Tea (mean) & 0 \\
Tea (max) & 0 \\
Coffee (mean) & 0 \\
Coffee (max) & 0 \\
\hline
\end{tabular}


The presented results and the current toxicological standards concerning the health risk related with the consumption of the analysed group of raw materials and products of plant origin in Poland do not indicate any concern resulting from the introduction of heavy metals, together with the diet, into the human organism. However, does the present state of knowledge allow stating without a doubt that the adopted toxicological standards are correct, especially as data on the effects of poisoning may appear after a long period of dormancy? In addition, the study indicates that, in particular, plant products originating in their majority from local production do not indicate any potential contamination of natural or agricultural areas with toxic elements.

Results published by us earlier, as well as those presented in this study, indicate that it is necessary to conduct research that would allow the estimation of the content of toxic elements in food products which have a significant contribution to our diet and could cause potential health problems $[77,78]$.

The contents of heavy metals in plant varied according to the character of soil, the pollution resource distribution, and the species of plant. Thus, the metal content level should be discussed taking into account the environmental condition. A dangerous phenomenon is the accumulation of heavy metals in the soil, which accumulate in the surface layer. The high concentration of heavy metals contributes to the degradation of the chemical properties of soils and to the contamination of ground and surface waters. When heavy metals are present in the soil in a dissolved form, they are absorbed by plants and accumulated in plant tissues. The most common source of soil contamination with heavy metals is represented by mineral fertilisers (mainly phosphorus fertilisers, followed by calcium, potassium, and nitrogen fertilisers) [79]. Monitoring studies from 1995-2010 showed no excessive contamination of soils in the Lublin region with heavy metals (including lead and cadmium). The increased levels of some metals observed locally did not significantly affect soil properties. No metal accumulation was observed in the soil surface layer for any of the heavy metals. [80].

Other results also confirmed the low level of heavy metals in the soil from arable land located along the busy section of the national road DK63 Siedlce-Łuków, particularly exposed to the effects of factors increasing the risk of heavy metals. In the studied soils located near the DK63 national road, the authors did not find any contamination with heavy metals. Regardless of the point of soil sampling, the amount of these elements was within the range of geochemical background values and did not exceed the permissible concentrations for agricultural use provided for in the Regulation of the Minister of the Environment, and it was within the range of natural content, developed by the Institute of Soil Science and Plant Cultivation (IUNG-PIB) in Puławy [80]. In another study, the total content of, among others, lead in the light soils of the Roztocze National Park buffer zone was determined. It is well known that, in light, usually acidic soils with a poor sorption complex, the negative effect of phytotoxic compounds, such as heavy metals, is most often revealed. The authors of these studies showed that the permissible values of heavy-metal concentrations were not exceeded in soils. Soils with such a heavy-metal content can be used for agricultural production without restrictions [81]. Other studies also confirmed that the content of heavy metals in the soils of the eastern region of Poland was relatively low and did not exceed the relevant standards $[82,83]$.

\section{Conclusions}

Summing up the results of the presented study, we can conclude that lead was the heavy metal assayed in the analysed samples with the highest concentrations. Its levels varied in the range from 0.010 to $5.680 \mathrm{mg} / \mathrm{kg}$. The element which was assayed in the analysed samples with the smallest amounts was mercury. Its content varied in the range from 0.005 to $0.030 \mathrm{mg} / \mathrm{kg}$. The level of contamination of the analysed samples with the toxic metals followed the decreasing sequence of $\mathrm{Pb}>\mathrm{Cd}>\mathrm{As}>\mathrm{Hg}$. A decidedly higher accumulation of the analysed heavy metals was noted in the analysed samples of herbs and spices $(0.005-5.680 \mathrm{mg} / \mathrm{kg})$, compared to the samples of tea and coffee 
$(0.005-0.791 \mathrm{mg} / \mathrm{kg})$. In reference to the guidelines of the World Health Organisation (WHO) concerning the limits of contamination of samples of herbal raw materials with heavy metals, lead concentrations in excess of the limit values were noted in only 24 samples of herbs (18\%). In all of the analysed samples of spices, tea, and coffee, no instances of exceeded maximum permitted levels were found for any of the analysed heavy metals. In the case of $\mathrm{Cd}$, the value of THQ was higher than that for the other monitored elements. Since the value of $T H Q \leq 1$, there was no probability of occurrence of unfavourable healthrelated effects caused by the consumption of the analysed group of raw materials and products of plant origin.

Funding: This work was financed by a statutory activity subsidy from the Polish Ministry of Science and Higher Education for the Faculty of Agrobioengineering of University of Life Sciences in Lublin.

Institutional Review Board Statement: Not applicable.

Informed Consent Statement: Not applicable.

Data Availability Statement: Raw data are available on request addressed to corresponding author.

Conflicts of Interest: The author declare no conflict of interest.

\section{References}

1. Kusuma, I.W.; Arung, E.T.; Kim, Y.U. Antimicrobial and antioxidant properties of medicinal plants used by the Bentian tribe from Indonesia. Food Sci. Hum. Wellness 2014, 3, 191-196. [CrossRef]

2. Duman, E.; Özcan, M.M. Mineral contents of seed and seed oils of Capparis species growing wild in Turkey. Environ. Monit. Assess. 2014, 186, 239-245. [CrossRef]

3. Brzezicha-Cirocka, J.; Grembecka, M.; Szefer, P. Monitoring of essential and heavy metals in green tea from different geographical origins. Environ. Monit. Assess. 2016, 188, 1-11. [CrossRef]

4. Tan, E.K.; Chua, E.; Fook-Chong, S.M.; Teo, Y.Y.; Yuen, Y.; Tan, L.; Zhao, Y. Association between caffeine intake and risk of Parkinson's disease among fast and slow metabolizers. Pharmacogenomics 2007, 17, 1001-1005.

5. Kotyczka, C.; Boettler, U.; Lang, R.; Stiebitz, H.; Bytof, G.; Lantz, I.; Hofmann, T.; Marko, D.; Somoza, V. Dark roast coffee is more effective than light roast coffee in reducing body weight, and in restoring red blood cell vitamin $\mathrm{E}$ and glutathione concentrations in healthy volunteers. Mol. Nutr. Food Res. 2011, 55, 1582-1586. [CrossRef]

6. Jabeen, S.; Shah, M.; Khan, S.; Hayat, M.Q. Determination of major and trace elements in ten important folk therapeutic plants of Haripur basin, Pakistan. J. Med. Plants Res. 2010, 4, 559-566.

7. Baye, H.; Hymete, A. Lead and cadmium accumulation in medicinal plants collected from environmentally different sites. Bull. Environ. Contam. Toxicol. 2010, 84, 197-201. [CrossRef] [PubMed]

8. Tripathy, V.; Basak, B.B.; Varghese, T.S.; Saha, A. Residues and contaminants in medicinal herbs-A review. Phytochem. Lett. 2015, 14, 67-78. [CrossRef]

9. Wallkers, M.P. Cadmium carcinogenesis. Mutat. Res. 2003, 533, 107-120. [CrossRef] [PubMed]

10. WHO (World Health Organisation). WHO Guidelines for Assessing Quality of Herbal Medicines with Reference to Contaminants and Residues; World Health Organ: Geneva, Switzerland, 2007.

11. Regulation of the Minister of Health of 27 September 2006. Amending the Regulation on the Methods of Sampling Certain Foods for the Official Control of the Levels of Pollutants and the Preparation of Samples and Guidelines for Analytical Methods for the Determination of These Pollutants. Available online: http:/ /isap.sejm.gov.pl/isap.nsf/download.xsp/WDU20061811336/O/D2 0061336.pdf (accessed on 19 May 2021).

12. Kowalska, G.; Kowalski, R.; Hawlena, J.; Rowiński, R. Seeds of oilseed rape as an alternative source of protein and minerals. J. Elem. 2020, 25, 513-522. [CrossRef]

13. Kowalski, R.; Kowalska, G.; Baj, A. The risk asessment of mercury poisoning after consuming teas and cereal products. Curr. Issues Pharm. Med. Sci. 2012, 25, 176-178.

14. Dadar, M.; Adel, M.; Saravi, H.N.; Fakhri, Y. Trace element concentration and its risk assessment in common kilka (Clupeonella cultriventris caspia Bordin, 1904) from southern basin of Caspian Sea. Toxin Rev. 2017, 36, 222-227. [CrossRef]

15. Fathabad, A.E.; Shariatifar, N.; Moazzen, M.; Nazmara, S.; Fakhri, Y.; Alimohammadi, M.; Azari, A.; Khaneghah, A.M. Determination of heavy metal content of processed fruit products from Tehran's market using ICP-OES: A risk assessment study. Food Chem. Toxicol. 2018, 115, 436-446. [CrossRef]

16. Means, B. Risk Assessment Guidance for Superfund; Human Health Evaluation Manual (Part A); Interim Final, Volume I; National Center for Environmental Assessement, Office of Research and Developments: Washington, DC, USA, 1989.

17. Newerli-Guz, J. Analiza rynku przypraw w Polsce. Mark. Zarządzanie 2017, 2, 167-175. [CrossRef]

18. CBI Product Factsheet: Tea in Poland. Available online: https://www.cbi.eu/sites/default/files/market-information/cbi_2016__tea_-_pfs_pl_-_final_draft.pdf (accessed on 24 March 2021). 
19. Chudy, S. Rozwój rynku kawy i zmiany w jej konsumpcji wśród Polaków. JARD 2014, 4, 1-10.

20. CBI Trade Statistics Spices and Herbs. Available online: https://www.ceintelligence.com/files/documents/Herbs $\% 20$ and $\% 20$ Spices\%20Sector\%20-\%20CBI\%20Trade\%20Statistics.pdf (accessed on 24 March 2021).

21. Chamannejadian, A.; Sayyad, G.; Moezzi, A.; Jahangriri, A. Evaluation of estimated daily intake (EDI) of cadmium and lead for rice (Oryza sativa L.) in calcareous soils. Iran. J. Environ. Health Sci. Eng. 2013, 10, 28. [CrossRef] [PubMed]

22. USEPA. Quantitative Risk Assessment Calculations; US Environmental Protection Agency USEPA: Washington, DC, USA, 2015. Available online: https:/ /www.epa.gov/sites/production/files/2015-05/documents/13.pdf (accessed on 12 February 2021).

23. Pawełczyk, A.; Božek, F.; Żuber, M. Environmental Risk, Case Studies. Czech-Pol Trade: Prague, Czech Republic. 2018. Available online: https:/ / depot.ceon.pl/handle/123456789/14664 (accessed on 12 February 2021).

24. IARC. Agents classified by the IARC monographs. In Oxford Handbook of Occupational Health; OUP Oxford: Oxford, UK, 2011.

25. USEPA, United States Environmental Protection Agency. Methodology for Deriving Ambient Water Quality Criteriafor the Protection of Human Health; EPA-822-B-00-004; USEPA: Washington, DC, USA, 2000.

26. Mirosławski, J.; Pakuszto, A. Determination of the cadmium, chromium, nickel, and lead ions relays in selected polish medicinal plants and their infusion. Biol. Trace Elem. Res. 2018, 182, 147-151. [CrossRef]

27. Krejpcio, Z.; Król, E.; Sionkowski, S. Evaluation of heavy metals contents in spices and herbs available on the polish market. Pol. J. Environ. Stud. 2007, 16, 97-100.

28. Gajewska, M.; Czajkowska-Mysłek, A.; Głowacka, A. Assesment of content of cadmium and lead in selected dried culinary plants. Post. Nauki Technol. Przem. Rol. Spoż. 2016, 71, 43-51.

29. Staniek, K.; Krejpcio, Z. Evaluation of $\mathrm{Cd}$ and $\mathrm{Pb}$ content in selected organic and conventional products. Probl. Hig. Epidemiol. 2013, 94, 857-861.

30. Fischer, A.; Brodziak-Dopierała, B.; Steuer, M.; Rajczykowski, K.; Kowol, J. The concentration of cadmium in spice plants available on the market and in individual growing areas. Environ. Med. 2017, 20, 27-33.

31. Chizzola, R.; Michitsch, H.; Franz, C. Monitoring of metallic micronutrients and heavy metals in herbs, spices and medicinal plants from Austria. Eur. Food Res. Technol. 2003, 216, 407-411. [CrossRef]

32. Reinholds, I.; Pugajeva, I.; Bavrins, K.; Kuckovska, G.; Bartkevics, V. Mycotoxins, pesticides and toxic metals in commercial spices and herbs. Food Addit. Contam. Part B 2017, 10, 5-14. [CrossRef] [PubMed]

33. Özden, H.; Özden, S. Levels of Heavy Metals and OTA in Medicinal Plants Commercialized in Turkey. Turk. J. Pharm. Sci. 2018, 15, 376-381. [PubMed]

34. Özcan, M.M.; Ünver, A.; Uçar, T.; Arslan, D. Mineral content of some herbs and herbal teas by infusion and decoction. Food Chem. 2008, 106, 1120-1127. [CrossRef]

35. Divrikli, U.; Horzum, N.; Soylak, M.; Elci, L. Trace heavy metal contents of some spices and herbal plants from western Anatolia, Turkey. Intern. J. Food Sci. Technol. 2006, 41, 712-716. [CrossRef]

36. Kohzadi, S.; Shahmoradi, B.; Ghaderi, E.; Loqmani, H.; Maleki, A. Concentration, source, and potential human health risk of heavy metals in the commonly consumed medicinal plants. Biol. Trace Elem. Res. 2019, 187, 41-50. [CrossRef]

37. Moghaddam, M.; Mehdizadeh, L.; Sharifi, Z. Macro- and microelement content and health risk assessment of heavy metals in various herbs of Iran. Environ. Sci. Pollut. Res. 2020, 27, 12320-12331. [CrossRef]

38. Ibrahim, G.I.; Hassan, L.M.; Baban, S.O.; Fadhil, S.S. Effect of heavy metal content of some common spices available in local markets in Erbil city on human consumption. Raf. J. Sci. 2012, 23, 106-114. [CrossRef]

39. Dghaim, R.; Khatib, S.A.; Rasool, H.; Khan, M.A. Determination of heavy metals concentration in traditional herbs commonly consumed in the United Arab Emirates. J. Environ. Public Health 2015, 973878, 1-6. [CrossRef]

40. Nordin, N.; Selamat, J. Heavy metals in spices and herbs from wholesale markets in Malaysia. Food Addit. Contam. Part B 2013, 6, 36-41. [CrossRef]

41. Meena, A.K.; Bansal, P.; Kumar, S.; Rao, M.M.; Garg, V.K. Estimation of heavy metals in commonly used medicinal plants: A market basket survey. Environ. Monit. Assess. 2010, 170, 657-660. [CrossRef] [PubMed]

42. Kumar, N.; Kulsoom, M.; Shukla, V.; Kumar, D.; Priyanka; Sanjeev, P.; Kumar, S.; Tiwari, J.; Dwivedi, N. Profiling of heavy metal and pesticide residues in medicinal plants. Environ. Sci. Pollut. Res. 2018, 25, 29505-29510. [CrossRef]

43. Wojciechowska-Mazurek, M.; Starska, K.; Mania, M.; Rebeniak, M.; Karłowski, K. Pierwiastki szkodliwe dla zdrowia w herbacieOcena zagrożenia dla zdrowia. Bromat. Chem. Toksykol. 2010, 43, 233-239.

44. Suchacz, B.; Wesołowski, M. The analysis of heavy metals content in herbal infusions. Cent. Eur. J. Med. 2012, 7, 457-464. [CrossRef]

45. Winiarska-Mieczana, A.; Kwiecień, M.; Kwiatkowska, K. Lead and cadmium content in herbal teas. Probl. Hig. Epidemiol. 2011, 92, 667-670.

46. Sarojam, P. Application Note. Atomic Absorption; PerkinElmer, Ed.; Bic USA Inc.: Shelton, CT, USA, 2011.

47. Zhong, W.S.; Ren, T.; Zhao, L.J. Determination of Pb (lead), Cd (cadmium), Cr (chromium), Cu (cooper), and Ni (nickel) in Chinese tea with high-resolution continuum Skurce graphite furnace atomic absorption spectrometry. J. Food Drug Anal. 2016, 24 , 46-55. [CrossRef] [PubMed]

48. Basgel, S.; Erdemoglu, S.B. Determination of mineral and trace elements in some medicinal herbs and their infusions consumed in Turkey. Sci. Total Environ. 2006, 359, 82-89. [CrossRef] [PubMed] 
49. Hosseni, S.M.; Shakerian, A.; Moghini, A. Cadmium and lead content in several brands of black tea (Camelia sinesis) in Iran. J. Food Biosci. Technol. 2012, 3, 67-72.

50. Adler, G.; Nędzarek, A.; Tchórz, A. Concentration of selected metals (Na, K, Ca, Mg, Fe, Cu, Zn, Al, Ni, Pb, Cd) in coffee. Zdr. Varst. 2019, 58, 187-193. [CrossRef]

51. Długaszek, M.; Połec, J.; Mularczyk-Oliwa, M. The content of chosen elements in coffee infusions depending on the method of their preparation. Bromat. Chem. Toksykol. 2010, 43, 493-497.

52. Alves da Silva, S.; Mendes, F.Q.; Reis, M.R.; Passos, F.R.; Xavier de Carvalho, A.M.; Rodrigues de Oliveira Rocha, K.; Pinto, F.G. Determination of heavy metals in the roasted and ground coffee beans and brew. Afr. J. Agric. Res. 2017, 12, 221-228.

53. Grembecka, M.; Malinowska, E.; Szefer, P. Differentiation of market coffee and its infusions in view of their mineral composition. Sci. Total Environ. 2007, 383, 59-69. [CrossRef]

54. Blagojević, S.M.; Blagojević, S.N.; Begović, B.M. Lead, Mercury and Arsenic Content in Spices: Black, White and Green Pepper, Black Cumin and Ginger. Facta Univ. Ser. Phys. Chem. Technol. 2015, 13, 191-202. [CrossRef]

55. Huremović, J.; Badema, B.; Muhić-Šarac, T.; Selović, A.; Memić, M. Heavy metal contents in spices from markets in Sarajevo, Bosnia and Herzegovina. Kem. Ind. 2014, 63, 77-81.

56. Alhusban, A.A.; Ata, S.A.; Shraim, A. The safety assessment of toxic metals in commonly used pharmaceutical herbal products and traditional herbs for infants in Jordanian market. Biol. Trace Element. Res. 2019, 187, 307-315. [CrossRef] [PubMed]

57. Gutt, G.; Amariei, S.; Norocel, L. Study of heavy metals in teas from romanian market. Rev. Chim. 2020, 71, 156-170. [CrossRef]

58. Othman, A.; Al-Ansi, S.; Al-Tufail, M. Determination of lead in Saudi Arabian imported green tea by ICP-MS. J. Chem. 2012, 9, 79-82. [CrossRef]

59. Behera, B.; Bhattacharya, S. The importance of assessing heavy metals in medicinal herbs: A quantitative study. TANG 2016, 6, 1-4. [CrossRef]

60. Mania, M.; Szynal, T.; Rebeniak, M.; Wojciechowska-Mazurek, M.; Starska, K.; Strzelecka, A. Human exposure asseessment to different arsenic species in tea. Rocz. Panstw. Zakl. Hig. 2014, 65, 281-286.

61. European Food Safety Authority. Scientific opinion of the Panel on Contaminants in the Food Chain (CONTAM) on arsenic in food. EFSA J. 2009, 7, 1-199.

62. Yuan, C.; Gao, E.; He, B.; Jiang, G. Arsenic species and leaching characters in tea(Camellia sinensis). Food Chem. Toxicol. 2007, 45, 2381-2389. [CrossRef]

63. Han, W.Y.; Shi, Y.Z.; Ma, L.F.; Ruan, J.Y. Arsenic, cadmium, chromium, cobalt, and copper in different types of Chinese tea. Bull. Environ. Contam. Toxicol. 2005, 75, 272-277. [CrossRef]

64. Shi, Y.Z.; Jin, L.M.; Zhu, Y.S. The contents status quo and the cumulation characteristic of heavy metal in tea. China Tea 2007, 6, 17-19.

65. Fischer, A.; Brodziak-Dopierała, B.; Loska, K.; Stojko, J. The assessment of toxic metals in plants used in cosmetics and cosmetology. Int. J. Environ. Res. Public Health 2017, 14, 1280. [CrossRef]

66. Kowalski, R.; Kucharski, A. Monitoring of total merkury level in selected herbal products. Herba Pol. 2007, 53, $235-240$.

67. Yu, I.S.; Lee, J.S.; Kim, S.D.; Kim, Y.H.; Park, H.W.; Ryu, H.J.; Lee, J.H.; Lee, J.K.; Jung, K.; Na, C. Monitoring heavy metals, residual agricultural chemicals and sulfites in traditional herbal decoctions. BMC Complement Altern. Med. 2017, 17, 1-9. [CrossRef]

68. Forsberg, J.; McQuatters, J. Mercury Determination in Tea Leaves, INCT-TL-1, USEPA Method 7473, Using the Teledyne Leeman Labs Hydra IIc Combustion CVAAS; Aplication Note-AN1603; Teledyne Leeman Labs: Mason, OH, USA, 2016.

69. Canadian Food Inspection Agency. Mercury in Dried Tea, Soft Drinks and Corn Syrup; Canadian Food Inspection Agency: Ottawa, Canada, 2011.

70. Soliman, N.F. Metals contents in spices and herbs available on the Egyptian market: Assessment of potential human health risk. Open Conf. Proc. J. 2015, 6, 24-29. [CrossRef]

71. Mihreteab, M.; Ketema, G.; Kassahun, H. Health risk assessment and determination of some heavy metals in commonly consumed traditional herbal preparations in Northeast Ethiopia. J. Chem. 2020, 7. [CrossRef]

72. Adusei-Mensah, F.; Essumang, D.K.; Agjei, R.O.; Kauhanen, J.; Tikkanen-Kaukanen, C.; Ekor, M. Heavy metal content and health risk assessment of commonly patronized herbal medicinal preparations from the Kumasi metropolis of Ghana. J. Environ. Health Sci. Eng. 2019, 17, 609-618. [CrossRef]

73. Nkansah, M.A.; Opoku, F.; Ackumey, A.A. Risk assessment of mineral and heavy metal content of selected tea products from the Ghanaian market. Environ. Monit. Assess. 2016, 188, 332. [CrossRef]

74. Asomugha, R.N.; Udowelle, N.A.; Offor, S.J.; Njoku, C.J.; Ofoma, I.Y.; Chukwuogor, C.C.; Orisakwe, O.E. Heavy metals hazards from Nigerian spices. Rocz. Panstw. Zakl. Hig. 2016, 67, 309-314.

75. Zhang, J.; Yang, R.; Chen, R.; Peng, Y.; Wen, X.; Gao, L. Accumulation of Heavy Metals in Tea Leaves and Potential Health Risk Assessment: A Case Study from Puan County, Guizhou Province, China. Int. J. Environ. Res. Public Health 2018, 15, 133. [CrossRef]

76. Winiarska-Mieczan, A.; Kwiatkowska, K.; Kwiecień, M.; Zaricka, E. Assessment of the risk of exposure to cadmium and lead as a result of the consumption of coffee infusions. Biol. Trace Elem. Res. 2020, 199, 2420-2428. [CrossRef]

77. Kowalska, G.; Pankiewicz, U.; Kowalski, R. Determination of the level of selected elements in canned meat and fish and risk assessment for consumer health. J. Anal. Methods Chem. 2020, 2148794, 1-13. [CrossRef] 
78. Kowalska, G.; Pankiewicz, U.; Kowalski, R.; Mazurek, A. Determination of the content of selected trace elements in Polish commercial fruit juices and health risk assessment. Open Chem. 2020, 18, 443-452. [CrossRef]

79. Malec, A.; Borowski, G. Assessment of soil contamination in the lubelskie province based on monitoring studies. Ecol. Eng. 2017, 18, 135-146. [CrossRef]

80. Kuziemska, B.; Pakuła, K.; Pieniak-Lendzion, K.; Becher, M. Heavy metals in soil along transport routes. Zesz. Nauk. UPH w Siedlcach Ser. Administracja i Zarzadzanie 2017, 39, 112.

81. Skwaryło-Bednarz, B.; Kwapisz, M. Assesment of the content of heavy metals and catalase activity in soil located in protected zone of the Roztocze National Park. Acta Agrophys. 2014, 21, 351-359.

82. Rolka, E.; Żołnowski, A.C.; Sadowska, M.M. Assessment of Heavy Metal Content in Soils Adjacent to the DK16-Route in Olsztyn (North-Eastern Poland). Pol. J. Environ. Stud. 2020, 29, 4303-4311. [CrossRef]

83. Mazurek, R.; Kowalska, J.; Gąsiorek, M.; Zadrożny, P.; Józefowska, A.; Zaleski, T.; Kępka, W.; Tymczuk, M.; Orłowska, K. Assessment of heavy metals contamination in surface layers of Roztocze National Park forest soils (SE Poland) by indices of pollution. Chemosphere 2017, 168, 839-850. [CrossRef] 